\title{
Mineral Resources of Gilgit Baltistan and Azad Kashmir, Pakistan: An Update
}

\author{
Muhammad Sadiq Malkani \\ Geological Survey of Pakistan, Muzaffarabad, Azad Kashmir, Pakistan \\ Email: malkanims@yahoo.com
}

How to cite this paper: Malkani, M.S. (2020) Mineral Resources of Gilgit Baltistan and Azad Kashmir, Pakistan: An Update. Open Journal of Geology, 10, 661-702. https://doi.org/10.4236/ojg.2020.106030

Received: March 26, 2019

Accepted: June 25, 2020

Published: June 28, 2020

Copyright (c) 2020 by author(s) and Scientific Research Publishing Inc. This work is licensed under the Creative Commons Attribution International License (CC BY 4.0).

http://creativecommons.org/licenses/by/4.0/ (c) (i) Open Access

\begin{abstract}
The Gilgit-Baltistan Province and Azad Kashmir regions are rich in mineral and natural resources. The gemstones, marbles and many other economic mineralizations are significant but these regions are relatively far from central and southern commercial areas of Pakistan. The gemstones of Gilgit-Baltistan Province are famous worldwide especially from Hunza and Skardu regions. The Azad Kashmir region also has a share of gemstone especially from the upper approaches of Neelam valley and marble, construction materials, coal, clays and other minerals found from different areas of Azad Kashmir. There is no common previous availability of comprehensive papers providing mineral data of Gilgit-Baltistan Province and Azad Kashmir regions. This report provides a quick view of mineral resources occurred in the Gilgit-Baltistan and Azad Kashmir regions.
\end{abstract}

\section{Keywords}

Mineral Resources, Gilgit Baltistan, Azad Kashmir, Pakistan

\section{Introduction}

All the mineral resources (except the radioactive/nuclear minerals and petroleum) are responsibility of federating units/provinces (Balochistan, Punjab, Sindh, Khyber Pakhtunkhwa), Capital Islamabad, Gilgit Baltistan and Azad Kashmir while the Radioactive minerals and Petroleum (oil and gas) are under the jurisdiction of Federal government of Pakistan. Keeping in mind this, the every province should know the potential of their mineral resources, so this paper on Gilgit Baltistan and Azad Kashmir (along with other papers on north Punjab, South Punjab, Khyber Pakhtunkhwa/KP, Balochistan and Sindh) is arranged for the easy approach and understanding of potential of their individual mineral resources. So as well planning for the development and exploitation of 
their mineral resources should be implemented. At the time of independence in August 1947, Pakistan was generally perceived to be a country of low mineral potential, despite the knowledge regarding occurrences of large deposits of salt, gypsum, limestone, marble, etc. During 1950-1980, the geological community of Pakistan can be credited with several major achievements in economic geology such as discovery of major gas fields in Balochistan, uranium from foothills of Sulaiman Range in Punjab and southern KP, barite from Balochistan and KP, chromite and China clay in KP, famous emerald in KP, copper-gold and lead-zinc in Balochistan and KP. What has been found so far is much too small than what is expected to be discovered in not too distant future [1]. From independence to so far many economic geologists presented revised and updated data and papers on mineral deposits of Pakistan. From the beginning of Pakistan, many geoscientists incorporated the new discoveries in the previous records and reported the review of mineral/minerals of Pakistan or part of it. The reference [2] presented a summary of known minerals of northwestern India (now Pakistan) with suggestions for development and use. The references [3] [4] reported economic minerals of Pakistan. The references [5] [6] [7] [8], recently [9] [10] presented a comprehensive report on mineral resources of Pakistan and [11] presented a report on mineral resources of Pakistan with basin and provinces wise which is easy for provinces to know their mineral resources. For easy approach, the mineral resources of each province like Balochistan [12]-[26], Khyber Pakhtunkhwa [24]-[32], North and South Punjab [24] [25] [26] [33] [34] [35], Sindh [24] [25] [26] [36] [37] [38], Gilgit Baltistan [24] [25] [26] [39] [40] and Azad Kashmir [24] [25] [26] [39] [40] and here also presented. Like this for the easy approach of mineral resources of each basin like Balochistan Basin [12]-[18] [23] [24] [25] [26], Siahan-Makran [12]-[18] [23] [24] [25] [26] (part of Tethys), Indus Basin subdivided into Kirthar Basin [14] [21] [22] [24] [25] [26], Sulaiman Basin [14] [19] [20] [24] [25] [26], Kohat Potwar Basin [24] [25] [26] [27] [28] and Khyber-Hazara-upper Kashmir basin (part of Gondwana plate or gondwanalands, southern Earth) [24] [25] [26] [27] [28], Kohistan-Ladakh (a part of Tethys) [24] [25] [26] [27] [28], Hindukush-Karakoram (a part of Tethys and Laurasian or Asian Plate or northern Earth) [39] also presented. For easy approach of revised stratigraphic setup of each basin like Balochistan Basin including fore arc (Makran-Siahan), arc (Chagai magmatic arc) and back arc (Pishin-Kaker-Khorasan) sub basins [14] [17] [18] [41] [42] [43] [44], (part of Tethys), Indus Basin subdivided into Kirthar Basin [14] [20] [21] [41] [42] [44] [45] [46], Sulaiman Basin [14] [17] [19] [20] [41] [42] [44] [45] [46], Kohat Potwar Basin [41] [42] [44] [45] [47] [48], and Khyber-Hazara-upper Kashmir basin (part of Gondwana plate or gondwanalands, southern Earth) [41] [42] [44] [45] [47] [49], Kohistan-Ladakh (a part of Tethys) [41] [42] [47], Hindukush-Karakoram (a part of Tethys and Laurasian or Asian Plate or northern Earth) [41] [42] [47] also presented. Recently many discoveries of gypsum and cement resources [14] [19] [20] [21] [22] [27] [28] [31] [33]-[38] [50] [51], fluo- 
rite [14] [15] [20] [21] [22] [52]-[57], celestite [14] [15] [19] [20] [21] [22] [55] [56] [57] [58], coal [59]-[71], clay and ceramic [72], barite [73] [74], gold-silver associated with antimony [14] [15] [17], K-T boundary minerals [75], construction materials, marble and other commodities [76]-[81] are made. Previously the Gilgit Baltistan and Azad Kashmir were received little attention but the present authors filled the missing link. This paper is comprehensive, easy access and easy to read for the researcher, mine owners and planners which add insights on mineral potential of Gilgit Baltistan and Azad Kashmir.

\section{Mineral Resources of Gilgit Baltistan, Pakistan: An Update}

The Gilgit-Baltistan Province includes gemstones resources (Figure 1) and gold (Figure 1) (Figure 2) and many other economic commodities (Figure 2). Besides gemstones (Figure 1), the Gilgit-Baltistan represents many important mineral resources (Figure 2) like arsenic (arsenopyrite, chalcopyrite, malachite, pyrite) from Dainyor Nala (15 km NE of Gilgit) and Bagrot Nala $(20 \mathrm{~km} \mathrm{~N}$ of Gilgit), bauxite from Chapursan (Hunza), gold in alluvial placer or sediments of Indus and Gilgit rivers and its tributaries which is being recovered by screen washing of stream sediments, copper and gold associated with gossans/red iron oxide/ochre and base metals of Karakoram (Shyok) Suture like Dainyor Nala (NW of Gilgit), Barit, Bulashgah (also magnetite pod in ophiolitic rocks), Majadar and Bor Nala, and Bagrot Nala, Henzil (10 km NW of Gilgit), Sher Qila (33 km NW of Gilgit), Singal (45 km NW of Gilgit), Nazbar valley (22 km W of Yasin), Shigari Bala area of Skardu and Golo Das and surrounding areas, iron from Indus Suture and its vicinity areas like Chilas, east of Gilgit, western, northern and eastern part of Haramosh massif forming lobe and possibly from Karakoram suture, lithium/lepidolite from Shengus of Nanga Parbat Massive (numerous pegmatites intruded in gneissic rocks), sheet mica/muscovite from many pegmatites like Astor, Bagarian and Hawa Gali, uranium from many areas; graphite from Nagar Hunza, Chalt and Chelish, Mesozoic coal from Chapursan valley, and widely exposed limestones and marbles, beautiful igneous and metamorphic different type of rocks from different areas [9] [10] [11] [24] [25] [26] [32] [39] [40]. Mineral and gemstones resources of northern areas including Gilgit Baltistan and Azad Kashmir were reported by many workers like [5] [8] [26] [82]-[117].

\section{Gemstone and Jewelry Resources}

Mineral and gemstones resources of northern areas including Gilgit Baltistan and Azad Kashmir (Figure 1) were reported by many workers like [5] [8] [26] [82]-[115] and here major sources for gold are [5] [8] [26] [82]-[117], and major sources for gemstones for the present report and also for our previous report [26] are [5] [8]. The different varieties of gemstones from Gilgit Baltistan were first reported in 1956 [114]. The Gilgit Baltistan province is very significant for gemstone resources because of hosting two main sutures like northern Indus and Karakoram (Shyok Suture). The high temperature created by geodynamics 


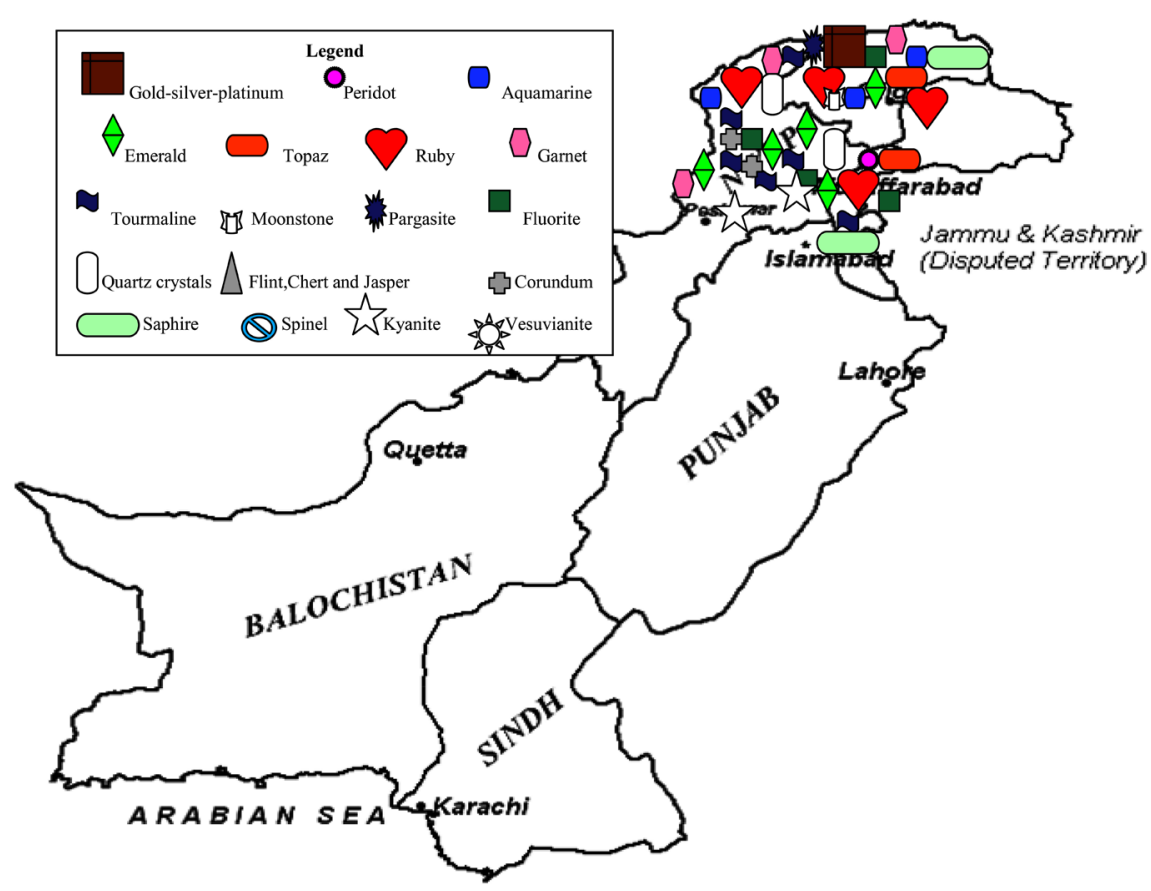

Figure 1. Map of Pakistan showing gemstone and jewelry resources of Gilgit Baltistan and Azad Kashmir and adjoining areas of Khyber Pakhtunkhwa (Pakistan).

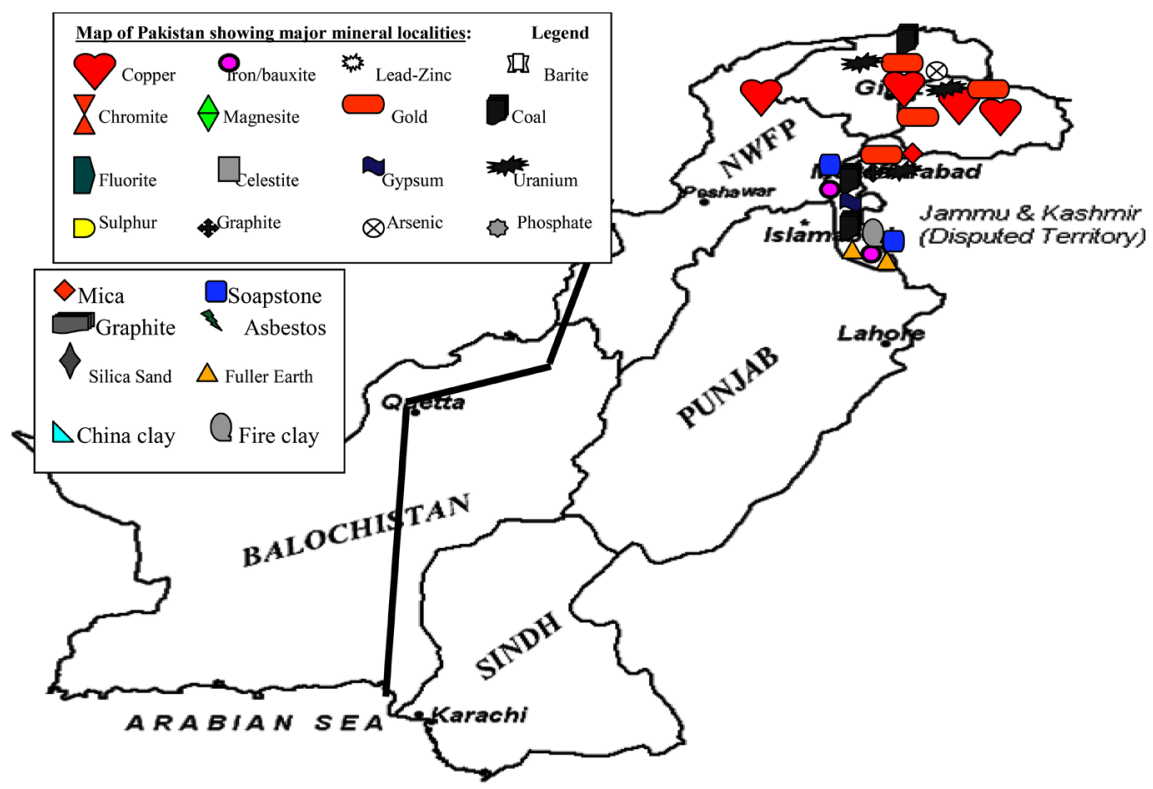

Figure 2. Map of Pakistan showing major mineral localities of Gilgit Baltistan Province and Azad Kashmir (Pakistan).

and tectonic collision of Indo-Pak subcontinent, so their sutures are producing gemstones and also significant for further exploration. Gemstones like aquamarine from Askere, Shingus, Dusso and Tisgtung of Gilgit; emerald from Khaltaro of Gilgit; moonstone from Shingus and Bulechi (Gilgit); quartz from Gilgit and Skardu; red ruby and spinel (magnesium aluminate) from Hunza are more attractive than Burma, and pargasite cabochons (green amphibolite; locally 
purchased as Hunza emerald) from Hunza valley; rose quartz from Dusso pegmatites near Skardu; topaz from pegmatites from Bulechi, Shingus and Gone near Dusso in Skardu; gem tourmaline (pink, blue, green and black) from pegmatites of Haramosh Range like Stak Nala between Gilgit and Skardu, Bulechi and Shingus; beautiful pyrite, malachite and azurite in pegmatite near Gilgit [9] [10] [11] [22] [23] [28] [29].

Gold-silver-platinum: The alluvial gold is being mined at small scale from different parts of Indus river from upper reaches to Attock like Gilgit, Chilas, Besham to Attock [8] [102]-[117]. In Northern areas under Gold Exploration and Mineral Assessment Project (GEMAP), carried by Australian Assistance during 1992-95, the integrated sampling and geochemical maps were prepared. Gold was detected in many hundreds of drainage cells (tributaries). Among these 24 sites shows high anomalous gold. These anomalies are mostly associated with major shear zone/Indus Suture and some are porphyry type intrusives or altered carbonates [103]. The upper reaches of Chitral, Gilgit and the Indus River in northern parts of Pakistan are well known for the placer gold occurrences [104]. The Bagrot valley [105], Shigari Bala area of Skardu [110] and Golo Das and surrounding areas [111] of Gilgit-Baltistan seems to be significant for gold and base metal mineralizations. Further the gold from the Ladakh area, the upper reaches of Skardu has been reported [112]. The devlopment of gold along with other gemstones can play a significant role for the development of the areas [113] is a good hope. This indicated the upper reaches of Indus and also Kabul river have the sources of dispersed primary gold but the transportation by water provided its richness at this level that it can be get from stream sedimnts screen washing and water panning in Indus river.

Aquamarine: It is a silicate of beryllium and aluminum and belongs to beryl group. It is reported from Dassu and Khaplu, Baltistan [5] [114]. It occurs in the pegmatites of Karakoram and NW Himalayas. Light blue aquamarine is most abundant in the gem pegmatites of Gilgit-Skardu area [99]. The better known deposits are Iskere, Shingus, Dusso and Tisgtung. These areas have good potential for deeper blue colour, high priced aquamarine and merits further exploration and development [8].

Emerald: It is a member of beryl group. It is fancied for its clear dewy green. It is due to Chromium content and in fact a green beryl without chromium would not be accepted as an emerald. Emerald is believed to posses healing power and to some people it is known as the healing stone. It is found in ophiolitic rocks of mélange zone of northern Indus Suture. The emerald deposits occur at near Khaltaro in Gilgit area. In short it has great potential for enhancing emerald production and mining activities [8].

Fluorite: It is used as a flux in making steel, in the manufacture of white and coloured opalescent glass, in enameling cooking utensils, for the preparation of Hydrofluoric acid and elemental fluorine and also ornamental use. The fluorite $\left(\mathrm{CaF}_{2}\right)$ mineralization is found in the Karakoram and Indus suture and adjoining 
zones associated with other gemstones [5] [8].

Xenotime: It is $\mathrm{YPO}_{4}$ with REEs replacing Y. Xenotime is widespread accesory mineral in granite. It is misidentified with zircon. It is associated with zircon, monazite, allanite and other REEs. It is common detritial heavy mineral in sands and placer deposits. The Gilgit Baltistan regions have wide exposures of granite which may yield xenotime gemstones.

Garnet: The more common minerals are Pyrope (glowing red colour), almandine (brownish red to reddish violet colour), rhodolite (rose red colour and strong luster), spessartine (most exquisite orange hue), grossularite (brown, reddish brown, clear sparkling copper-gold to green), demantoid (unusual and rare among garnets and fancied for its brilliance and fire with refractive index 1.89. As a birthstone for those born in January, it symbolizes fidelity, friendship and constancy. It is reported from Bash-Shigar and Khaplu Baltistan [5] and Harmosh range Gilgit [97]. Gem quality red spessartine is associated with pegmatites of Dusso and Shingus in northern areas which yielded large transparent crystals [8]. Garnet hosted by tonalite in the Chilas complex in Kiner Gah area of Chilas [118].

Kyanite: The Kyanite-garnet bearing tonalite, which is reported for first time from the Chilas complex in Kiner Gah area of Chilas [118].

Moonstone: It is a rock forming feldspar. It is soft grey to spring clear, silvery white, reddish brown to light blue. It is the birthstone of June and is believed to bring happiness and good fortune. It has been mined from pegmatites of Shingus and Bulechi in Gilgit Agency. The deposits are large with good quality. The adularia feldspar is called sunstone [8].

Pargasite: It belongs to monoclinic amphibole. Exquisite deep pistachio green crystals of pargasite occurred in metamorphosed crystalline marbles along with ruby and spinel in the Hunza valley. It is translucent to opaque and used into beautiful cabochons. Locally they are sold as Hunza emeralds [8].

Quartz crystals and jewelry: Quartz crystals are found in pegmatites and suture areas. These crystals can be used in best jewelry for attraction as diamond because India is famous due to using diamond in jewelry. Pakistan has many quartz crystals deposits. For detail, see in quartz veins title. It is used as gem and also used for dishes, optical instruments, spectacles, chemical, radio appliances, frequency control in electrical and radio apparatus. It is silicon dioxide and common rock mineral and also includes a number of ornamental varieties. The ornamental varieties can be crystalline such as amethyst and citrine or cryptocrystalline such as opal, agate, chrysoprase, chalcedony, and cornelion. The violet quartz or amethyst is the birthstone for the February born and to symbolize durability, friendship and stead fastness in love. Clear and well formed crystals of quartz occur in gem pegmatite in Skardu and Gilgit areas. Smoky quartz occurs in these areas also. Rose quartz is abundant is Dusso pegmatites near Skar$\mathrm{du}[8]$.

Corundum: Its gem varieties are ruby sapphire (red), oriental amethyst 
(blue), oriental emerald (green) and oriental topaz (yellow). It is found in the suture and vicinity areas [8].

Ruby: It belongs to olivine family. It is the birthstone for the month of August and it is said to put ghosts and demons to flight, dispel melancholy and foolishness and to show the eternal paths to wisdom. It is reported from the marble of Bashe-Highar and Strakin Rondu, Baltistan [5] [114]. The main deposits occur in the dolomitic marble extending for over $100 \mathrm{~km}$ from Hunza valley to Ishkoman, close to Main Karakoram Thrust. Mining is confined to 13 mining centers spread over a length of $15 \mathrm{~km}$ in Hunza Valley. Thus there is great potential for development of ruby deposits in Pakistan. The host marble of this region also contains the minerals like sapphire, spinel, pargasite, margarite, phlogopite, chlorite, graphite, pyrite, rutile, dolomite, sphene, apatite, tourmaline, plagioclase, pyrrhotite, quartz, calcite, and goethite [98] [119].

Sapphire: It is found in the Illaga Khorming Baltistan [5] [114].

Spinel: It is a group with magnesium aluminium oxide composition. It is admired for its lovely vibrant colors, strong brilliance, and striking clarity. It can be withstand great heat without change and occurs in an extremely beautiful variety. Purple to blue and blue green varieties are also common. Spinal with its ruby red colour is closely associated with Hunza ruby deposits [120]. The red colour of spinel is due to presence of chromium, where as the bluish and plum (Alu Bukhara) colored varieties owe their colour to the presence of iron [99]. The Hunza spinels are larger than those customarily found in Burma and are far more attractive [8].

Topaz: It is fancied for its glowing, fiery sparkle and its wide range of colors ranging from yellow to golden brown, rose red to peach (Aro or Shuftalo) pink, blue to shining azure/sky blue and colorless to pure white. The yellow variety resemble citrine (yellow quartz), but it is more attractive mainly due to its higher refractive index (1.62), hardness 8 , and specific gravity 3.5 - 3.6. They mostly found in microcline-quartz-muscovite matrix. Topaz bearing pegmatites are found at Bulechi, Shingus and Gone near Dessu in the Skardu area. It is reported from Harmosh range, Iskere valley Gilgit [97]. It is found in Pakistan and if properly and correctly promoted in world market, its price can be very greatly enhanced [8].

Tourmaline: It is famous for its beautiful colors, occurring in all possible hues and shades. The more common hues are ruby red (rubellite), orange through brown to yellow, green and blue (indicolite). The gem varieties include rubellite, dravite, elbaite and liddicoatite [99]. It is believed to be stone for the October-born and is said to speed the writers' flow of thought. It is reported from Khaplu Baltistan [5] [115], Harmosh range [97]. It is found in the pegmatites of the Haramosh range near Gilgit, Stak Nala (Between Gilgit and Skardu), Bulechi and Shingus (Gilgit Division). Some of the best and fairly large specimens of bicolor and tricolor tourmaline have been found in these pegmatites [8] [100].

Pegmatite gems and other mineral specimens: The pegmatites from north- 
ern areas have yielded excellent specimens like light pink crystals of fluorapatite, fluorite, green microcline, aquamarine, tourmaline, topaz, garnet, spessartine, hambergite, morganite (rose coloured variety of beryl), goshenite, epidote, quartz [8] [121]. Black Tourmaline/schorl is ubiquitous in entire gem localities of northern areas [122]. Beautiful pyrite, malachite, and azurite specimens can be collected near Gilgit. The reference [96] reported production of some gemstones from Pakistan like agate, actinolite, amazonite (feldspar/microcline), azurite, epidote, jadeite (nephrite is a jade), Kunzite (transparent variety of spodumene pyroxene), margarite (the mineral of hydrated silicate of $\mathrm{Ca}$ and $\mathrm{Mg}$; with pearly luster), pargasite (hornblende), rutile, serpentine, turquoise (phosphate minerals), sapphire (blue variety of tourmaline), lapis lazuli (lazurite, feldspathoid group), tripoli (weathered chert/siliceous limestone).

Peridot: It belongs to olivine family. It is the birthstone for the month of $\mathrm{Au}$ gust and it is said to put ghosts and demons to flight, dispel melancholy and foolishness and to show the eternal paths to wisdom. It is found near the Kohistan-Kaghan watershed to the NE of Naran. It occurs along shear zones and in pockets in dunitic host rocks and are associated with clinochlore, magnetite and magnesite. It occurs in the immediate hanging wall of the Indus Suture and possibly it may be found in the hanging wall of Karakoram suture. It represents the basal cumulates of the Sapat mafic-ultramafic complex [123]. It is transparent to translucent and pale to dark yellowish green, rarely greenish yellow. The Peridot is mostly $\mathrm{FO}_{91}$ in composition but ranges from $\mathrm{Fo}_{90}$ to $\mathrm{Fo}_{94}$.

Nephrite Jade: Nephrite is silicate of calcium and magnesium. Jadeite is silicate of sodium and alluminium. Nephrite upto about $10 \mathrm{~cm}$ lump is reported from river bed may be derived from Siwalik conglomerate at the junction of Teri Toi stream with the Indus river and confluence of Teri Toi and Pathan Algad in Kohat district [124]. Nephrite is originally may be derived from ultrabasic rocks and formed by metamorphism [5]. So its source rocks are in northern areas, so its exploration from basic/ultrabasic rocks of Gilgit Baltistan can reveal better results.

Exploration of gemstones in alluvial and bed rocks; Gemstones commonly being collected from bed rocks. Howver gold and many gemstones being collected from river beds, stream sediments and alluvial placer deposits in many rivers and streams by stream sediments washing methods. In some countries like adjoining India, the rare earth elements bearing monazite is being obtained from alluvial deposits. In this way [125] reported rare earth bearing gemstone Bastnasite (carbonate fluoride'; honey yellow to reddish brown). The author suggests that the governments should facilitate those who working on stream sediments washing methods for gold, gemstones and also may be encouraged for other heavy minerals like monazite, zircon, rutile, ilmenite, etc. rare earth bearing gemstone (Bastnasite)

Metallic and non-metallic Mineral Resources

Arsenic: It is produced mainly as a by product in the smelting of the copper 
and lead ores. The chief mineral that yield arsenic are arsenopyrite, realgar, orpiment and tetrahedrite. Less important are native arsenic, niccolite, cobaltite, smaltite, proustite and enargite. Short metal is an alloy of arsenic and lead. Arsenic oxide is used in the manufacture of insecticides, such as Paris green, and the arsenates of calcium, lead, manganese and magnesium. It is also used to counteract the iron coloration in the manufacture of glass. Arsenic compounds are also used in the preservation of wood and as pigments and in allopathic medicine. Orpiment and realgar are said to be used in ayurvedic medicine. It is being produced from Khyber Pakhtunkhwa. The orpiment and realgar are reported from Gilgit-Baltistan regions. They are associated with marbles and calcareous shales. [126] [127] [128] reported these mineralizations from lower Hunza valley and Dainyor and Bagrot nalas, NE and E of Gilgit. Arsenopyrite, chalcopyrite and pyrite occur in Dainyor and Jotiyal nalas in Gilgit District and surroundings. The arsenide deposits of economic importance occur near Hunza, Gilgit belts and their beneficiation studies of eight samples from these deposits were undertaken by Atomic Emission spectrography [129].

Copper, lead and zinc: The copper bearing minerals like chalcopyrite and malachite and pyrite reported from Dainyor or Danyor Nala (15 km NE of Gilgit), Bagrot Nala (20 km N of Gilgit) and Jotial Nala [126] [127] [128]. Copper minerals and pyrite in quartz veins upto $2 \mathrm{~m}$ thick in hornblende gneiss and schist which are intruded by granite in Jotial (Jutial) Nala $5 \mathrm{~km}$ from its mouth which is $8 \mathrm{~km}$ to the south of confluence of the Gilgit and Hunza rivers [126]. This Nala is about $8 \mathrm{~km}$ long and has agradient of about $350 \mathrm{~m}$ per $1 \mathrm{~km}$ [126]. Murkui area shows malachite in quartz veins cutting schist which is about 2.5 $\mathrm{km}$ to the southwest of Murkui village in Daimyer Nala, about $13 \mathrm{~km}$ above its mouth which is on the eastern bank of Hunza river, about $3 \mathrm{~km}$ above its confluence with the Gilgit River. Indus, Gilgit, Nagar and hunza rivers show chalcopyrite in the heavy mineral sands from srtream sediments. It is necessary to mention that the copper mineral is not reported from any of the small tributaries of these rivers [4] [5] [126] [127] [128]. The copper mineralization reported in Surgin glacier area, Gilgit area [130]. The reference [131] mentioned the hydrothermal alteration and carried the sulphur isotopic study of sulphide deposits, Gilgit area. The reference [132] reported the occurrences of sulphide mineralization in Singal area (42H/16) Gilgit District. The reference [133] mentioned Lead investigation in Lichi area, Gilgit district. The Chagai magmatic arc and Kohistan-Ladakh magmatic arc, both are produced by subduction of sea plates. The Chagai arc is produced by subduction of Arabian sea plate which resulted prominent copper-gold deposits of Saindak, Rekodiq and others. The Kohistan-Ladakh magmatic arc is also produced by subduction of Tethys sea plate which is stressed by Indo-Pakistan continental plate when reached close during late Cretaceous just before the collision. Now chagai arc have prominent copper gold deposits while Kohistan-Ladakh arc has no so far copper gold deposits. But there are many indications of being large deposits. The first maina reson is the 
anomalous gold and copper mineralization in the vicinity of Gilgit and Hunza areas surrounding its confluence. The second main reason is the detail sampling and work done in Chagai magmatic arc, while sampling and detail work is needed in Kohistan Ladakh arc along with its contacts or sutures like northern contacts (Karakoran Suture) and southern contact (Indus suture/northern Indus suture). However the topography of both arcs is different. The Kohistan Ladakh arc is relatively difficult in accessibility for detail work and samplings. But it may be possible in future these areas may produce good deposits. Recently [134] carried work and as a result detail work is recommended in Danyor Nala.

Graphite: In Pakistan no economic graphite deposits are found so far. Only amorphous graphite showings are found. Most of the accessibilities are difficult. It occurs in Chalt located $50 \mathrm{~km}$ from Gilgit on the Gilgit-Hunza Nagar road, District Hunza-Nagar [5], Chhelish and Bola Das of Yasin District, [5] and Stak-Pondu Shigar Nala of Gilgit-Baltistan Province [128]. The reference [135] mentioned the graphitised coal of Chapursan valley, upper Hunza valley.

Iron: Iron is found in Indus and Karakoram sutures and its vicinity areas like some areas of Chilas, east of Gilgit, western, northern and eastern part of Harmosh massif forming lobe. The reference [136] mentioned iron ore resources.

Millstone, quartzite and quartz powder: The hard and compact granite/quartzite found in the area can be used as millstone and quartz powder.

Nickle and cobalt: The reference [137] reported anomalous $\mathrm{Ni}, \mathrm{Cr}$ and $\mathrm{Co}$ in the ultramafic rocks of Teru, Yasin and Pakora areas of Karakoram suture (Shyok suture).

Pyrite: Pyrite or iron pyrite is reported in the slates of Gilgit regions from north of Normal near Hottar peak, six kilometers south of Normal, in Dainyor Nala and in Jutial Gol the 10 kilometers to the southeast of Gilgit town [4]. The normal pyrite deposits were reported in slate upto maximum $25 \%$ concentration of pyrite, while in Jutial Gol the moderate deposit of pyrite were reported in quartz vein which is about 2 meter/m thick and over $150 \mathrm{~m}$ long [4]. Further pyrite nodules are common in the sedimentary, metamorphic and igneous rocks of different ages. The reference [138] reported pyrite deposits of Naz bar area, Yasin valley, Gilgit district, Northern area, Pakistan.

Quartz veins: These are reported from north of Normal near Hottar peak, near Normal (25\% pyrite in slates), in Dainyor Nala and Jutial Gol (pyrite in quartz veins) near the Gilgit town, Gilgit Agency [4]. Further these are widely exposed in the Astore, Skardu and different areas of Gilgit Baltistan.

Sheet mica/muscovite: Mica splits in to thin sheets which are strong, flexible, chemically inert, and transparent. Muscovite is used in electrical, machinery and other industries. Transparent sheets are also used for windows in coal, gas and oil stoves, gas lamps chimneys and lamp shades. Scrap mica is used in the manufacture of wall paper, gypsum plaster board, cement, lubricants, fancy paints, electrical insulators and micanite. Phlogopite is used as insulator in electrical apparatus. For commutators, phlogopite is preferred. Lepidolite is a common 
source of lithium compounds. Muscovite occurs in granites and syenites and pegmatites and also common in gneisses and schists. Phlogopite occurs in crystalline limestone, dolomite, schists and serpentine. Mica or Lepidolite occurs in pegmatite veins, granite, gneisses and sands. [139] and [127] reported mica from different northern areas. The used mica is muscovite, phlogopite (yellow to green copper or bronze red) and Lepidolite (rose red). Muscovite is found in pegmatites near Baltit, Hyderabad in Hunza state, Dasu in Baltistan, Shigar, Shengus, Astor etc in Gilgit-Baltistan [5] [8]. The mica sheets are rather small, usually less than $0.3 \mathrm{~m}$ in size, in Karakoram block limited and sporadic mining has been done near Baltit and Dassu [8]. Lithium/lepidolite is reported from Shengus or Shingus of Nanga Parbat Massive (numerous pegmatites intruded in gneissic rocks) [140].

Soapstone and talc: Soapstone small deposits occur as veins in ophiolitic complex in the Indus and Karakoram sutures.

Heavy mineralizations: The heavy mineralizations of gold, zircon, rutile, ilmenite, magnetite, monazite, tungsten, Rare Earth Elements, and others reported from stream sediments in Indus River and its tributaries. The anomalous results of stream sediments shows the host deposits which may be dispered or concentrated deposits and further revealed its concentration in alluvial deposits. In short the alluvial and placer deposits are significant for these heavy minerals exploitations.

Mercury: Hg has many uses and also hazardous for human and climate. [141] mentioned the anomalous results of mercury in trees and soils along Gilgit, Hunza and Indus rivers indicates the sources deposits of mercury in the catchment areas of Gilgit, Hunza and Indus rivers occurred.

\section{Cement Raw Material Resources}

Cement raw material includes limestone $75 \%$ and clays/shale $25 \%$ for clinker preparation and further it needs Gypsum 5\% as retarder. The limestone/marbles and shale/slates/phylites and siliceous igneous rocks are found in the reported area, so cement industry can be installed. Only gypsum will be required from Khyber Pakhtunkhwa/north and south Punjab/Balochistan.

\section{Ceramic Mineral Resources}

Large amount of igneous rocks, quartz veins and limestone/marble are found in the area.

Construction, dimension and decorative stone resources

These are extensively used in the construction industry, for decorative purposes in building facings, bath rooms and for floor tiles. It is used for making handicraft items. Pakistan and also the reported areas consist of huge marble and limestone resources [142] [143] [144]. The most commonly used are simple marble, onyx or banded marble, various types of limestones and igneous rocks, mainly granite, dolerite etc. Attractive and good quality marble/limestone/dolomitic limestone, granite, dolerite dykes, serpentine, slate stone, quartzites, are found in different areas of Gilgit Baltistan. 


\section{Coal Resources}

The reference [135] mentioned the graphitised coal of Chapursan valley, upper hunza valley. The northern areas were considered barren for coal but a showing of coal has been reported in Jurassic limestone of Reshit area. Reshit Coal is located $6 \mathrm{~km}$ south of Reshit village in Chapursun valley about $40 \mathrm{~km}$ west of Sost (150 km north of Gilgit) on Karakoram highway. Small lenses of coal are found in the Jurassic Ashtigar formation which consists of greenish grey splintery shale, marl with sandstone, dolomite, limestone with radiolarian chert and coal, unconformably overlain by Cretaceous Yashkuk formation which consists of red sandstone, calcarenite, conglomerate, shale and sandstone. A mining feasibility was carried out by Agha Khan Rural Support Program (AKRSP). AKRSP carried adits and at depth coal finished [71], Fuel research centre and HDIP). The Jurassic and early Cretaceous rocks are widely exposed in entire length of Chapursun valley and extend in to Wakhan valley of Afghanistan. Coal was being mined from Wakhan valley Afghanistan and also reported by local people. A detailed study can prove the existence of economical deposits. However the coal blending process like mixing of low quality coal with high quality coal by any methods like blending in bed, blending by silo, blending by ground hopper and blending on moving belt (most common) can produce required results for thermal power or any other uses [145]. Further the reference [146] mentioned that "it was observed that (Aluminum, Arsenic, Barium, Bromine, Calcium, Cerium, Cobalt, Chromium, Cesium, Copper, Iron, Gallium, Hafnium, Lanthanum, Manganese, Molybdenum, Niobium, Neodymium, Nickel, Lead, Rubidium, Antimony, Scandium, Selenium, Silicon, Tin, Strontium, Samarium, Tantalum, Titanium, Uranium, Vanadium, Tungsten, Ytterbium, Zink and Zirconium elements were present in all the coal samples from Thar coal" which have adverse effect on the health of the living organisms intact with coal utilization. Some of these elements such as Arsenic, Barium, Beryllium, Chromium, Cobalt, Copper, Lead, Molybdenum, Nickel, Selenium, Uranium, Vanadium and Zinc are extremely harmful to human health, if released to the environment during coal combustion. Therefore, the coal samples were being demineralized with washing the coal samples with standard solution of $2 \mathrm{~N} \mathrm{HCl"}$. Now the author suggest that it may be possible the Thar and also other coal deposits in $\mathrm{Pa}$ kistan may host all or some said elements. Some of these elements found in coal have industrial importance can be separated and exploited by suitable washing methods.

\section{Petroleum Resources}

Due to dominant igneous rocks and severe shear zones due to tectonic and geodynamics of Indo-Pakistan plate, the area is not significant for petroleum prospecting, however the northern part of Karakoram belt the sedimentary rocks belonging to Eurasian/Asian plates can be tested for petroleum exploration.

\section{Radioactive Mineral Resources}

The radioactive minerals of uranium, thorium, etc occur primarily in the ig- 
neous rocks especially in the northern Indus Suture, Kohistan-Ladakh, Karakoram blocks. Uranium concentration is increasing toward east in Karakoram, may be correct for gold. It is enriched in Gilgit-Baltistan. The monazite associated rare earth elements along with thorium and small amounts of uranium may occur in higher areas. The monazite may found with the heavy mineral concentrates like ilmenite, sillimanite, garnet, rutile, zircon minerals after water panning done in Indus river sands. The reference [147] reported uranium occurrences in magmatic and metamorphic rocks of northern Pakistan and reference [148] reported survival factor of uraninite in the major rivers of Gilgit, Kohistan and Indus Basin, northern Areas and the reference [149] carried the study to quantify the indoor and outdoor gamma radiation level, the associated effective dose rate and Lifetime Cancer Risk in Gahkuch, the capital city of district Ghizer in the eastern Hindukush and concluded this area has high dose rate of gamma radiation.

\section{Rare Earth elements (REE) and thorium}

The Rare earths are a class of 17 rare earth elements that are extensively used for information technology, computer, clean energy systems, health care, defense production, advanced transportation services, rechargeable batteries, catalytic converters, fluorescent lightings, cell phone and many others. The applied as well as research sector organizations of developed countries are the major consumers of REEs as they increase the efficiency of solar cells, wind turbines and other renewable energy systems. The reference [150] mentioned that the REEs are primarily hosted in minerals like apatite, monazite, chevkinite which are found in alkaline rocks including alkali granites, syenites, nepheline syenites, carbonatites and albitites which occurred in Tarbela, Ambela (Buner), Jambil (Swat), Warsak (Peshawar), Sillai Patti (Malakand), Loe-Shilman (Khyber Agency) and possibly in different places of northern Pakistan. The rare earth elements occur primarily in the igneous rocks while it is also found in sedimentary and metamorphic rocks. The Gilgit Baltistan hosts different type of igneous rocks like acidic, intermediate, basic and also ultrabasic intrusive and volcanic. Further Gilgit Baltistan host the varities of metamorphic rocks and sedimentary rocks and also host the vast placer deposits around Skardu, Gilgit and other areas and can be explored for REEs. REE are commonly associated with other mineral deposits like iron, fluorite, carbonate, etc which are commonly found in Gilgit-Baltistan. The rare earth elements are associated with heavy minerals (for example in India) like ilmenite, sillimanite, garnet, zircon, monazite and rutile, collectively called beach sand minerals (BSM). These minerals may be called heavy mineral concentrates because they are collected as heavy mineral residue on screen washing or water panning or magnetic or oil or any other heavy mineral concentrates methods. It is necessary that these heavy minerals are not major source of uranium. However the monazite may have associated rare earth elements along with thorium and small amounts of uranium. Last decades witnessed the shift of policies from petroleum to rare earth elements (REE) driven 
economy. To cope and adjust with the present and future needs, geological exploration in Gilgit Baltistan, Azad Kashmir and other provinces of Pakistan will be accelerated in primary and especially in secondary rocks (alluvial, eolian and placer deposits). The reference [151] mentioned the differentiation criteria of carbonatites and marble like the presence of pyrochlore can be a good indicator of carbonatite, but its absence cannot characterize marble, and the $\mathrm{MnO}$ and $\mathrm{SrO}$ contents of carbonate minerals may be used as indicators to distinguish carbonatites from marble. The reference [152] reported that the REE potential in younger Loe Shilman and Sillai Patti (30 Ma) and the older Koga and Jambil (300 Ma) carbonatites deposits of Pakistan. Their coeval, sandwiched and cogenetic rocks in the north and eastwad extension toward the Gilgit Baltistan and Neelam area of upper Azad Kashmir (north Azad Kashmir) is also significant for primary precious and rare earths. Carbonatites are significant because of producing large-scale sources of niobium, cerium, apatite, magnetite, barite, vermiculite, phosphorus, tantalum, uranium, thorium, copper, iron, titanium, vanadium, barium, fluorine, zirconium, and other rare or incompatible elements, which meets the industry demands. Further in some reports mentioned the RRE affinity with ocean clay. Although Gilgit Baltistan and Azad Kashmir have no oceanic contact but Pakistan has long oceanic beach and sea in the south.

\section{Geothermal Energy Resources}

Geothermal hot springs reported are near Chilas and many other places in Gilgit Baltistanand surrounding regions are Tatta Pani, Tatto, Murtazabad, Sassi, Chutran, Budelas, Mushkin, etc, in northern areas (surface temperature from $35^{\circ} \mathrm{C}$ to $94^{\circ} \mathrm{C}$ ). All the thermal water is neutral to slightly alkaline. $\mathrm{Na}$ is dominant cation in all cases with different anions like $\mathrm{HCO}_{3}, \mathrm{SO}_{4}$ and mixed type. The results indicate a good potential of these resources for industrial, domestic, electricity generation, heating and dry ice making purposes [153] [154].

\section{Water Resources and Dam Constructions}

Gilgit Baltistan area has a lot of potential for glacier water, perennial water, diversion dams and tunnel channels for power generations and small and large dams for water storage and also power generations [9] [10] [11] [39] [60]. The Indus and Gilgit rivers and their main tributaries have vast potential for water dams and diversion dams for water storage and hydel electricity production for local and regional developpments. The tunnel hydel power project (if feasible) can be started in Gilgit Baltistan like Neelum Jehlum and Lowari tunnel power projects of Azad Kashmir. It is encouraging the government has started the work on Skardu dams, Basha, Mohmand and Dassu dams for water storage and hydel power and also hopes many diversion dams for hydel power which are vital for the sustainable development of regions, country Pakistan and Gilgit Baltistan. The water storage of small and large dams can be used for agricultural purposes of Gilgit Baltistan, Khyber Pakhtunkhwa, Punjab, Balochistan (Dera Bugti, Nasirabad and surroundings via Kachi canal from Taunsa bridge), and Sindh provinces [60]. 


\section{Mineral Resources of Azad Kashmir, Pakistan: An Update}

The northern Indus Suture and Shyok Suture and adjacent areas, and major faults with high shear density in Karakoram, Kohistan and NW Himalayas are the main target areas for gemstones (Figure 1) and minerals (Figure 2) exploration. Azad Kashmir territory is divided into two basins: The upper Azad Kashmir (from Nausehri-Sharda-Kel-Taubat) and lower Azad Kashmir (from Muzaffarabad to Kotli-Mirpur) basins. The upper Azad Kashmir is correlated with Khyber-Hazara basin, so upper Kashmir is an eastern extension of Khyber-Hazara basin and named as Khyber-Hazara-upper Kashmir basin (uppermost Indus basin). The lower Kashmir is correlated with Kohat-Potwar basin, so lower Kashmir is an eastern extension of Kohat-Potwar basin and named as Kohat-Potwar-lower Kashmir basin (upper Indus basin). Azad Kashmir generally considered barren for mineral resources but it is not true. It hosts many economic mineral commodities which can provide an innovation for the sustainable development of Azad Kashmir. The installation of marble and other dimension stone industries are very significant for the sustainable development of Azad Kashmir which can use marbles from Nausehri-Jhugian, dolomite/dolomitic limestone from Muzaffarabad, Nauseri, Goi, Dhanwan, Nikial, etc., granite, dolerite and quartzite from many localities of Neelam valley. The construction stone resources from many localities are very significant for the sustainable development of Azad Kashmir. The installation of Cement Industry on dolomitic limestone of Muzaffarabad and Kotli regions and Pozaloan cement in Kalamula-Kailer-Lamnian-Nauseri belt (eastern flank of Hazara-Kashmir syntaxis) are again very significant for the development of the area. The area has large reserves of cement raw materials like dolomitic limestone, clays/shale and some gypsum deposits. The installation of pulverizing plant for gypsum/anhydrite around Muzaffarabad and Reshian can provide plaster of Paris for local consumptions. Further water resources which are again very significant and can play an important role for the development of the area like diversion dams and water storage dams will overcome the energy crises and scarcity of agricultural water in Azad Kashmir and Pakistan. Tattapani thermal hot springs can provide geothermal energy for heating rooms of Tatta Pani town during winter. The planning for the development of fire clay, bauxite and laterite/iron from Kotli, Muzaffarabad and Reshian can also share for the development of the areas. The development of some mineral commodities is also in process like gemstones from upper Neelam areas (green tourmaline/indicolite and rubellite from $\mathrm{Gu}$ rais, black tourmaline/Schorl, garnet and quartz from Jandran Wala, aquamarine, beryl and topaz from Gurais and Donga Nar found in pegmatites and ruby from Nangimali, Kalajandar and Naril areas found in marble); coal from Kotli and Muzaffarabad areas; and bentonite from Bhimbar, Dodial and Mirpur areas. The extrapolation of petroleum resources in the southern and southwestern part of Azad Kashmir which is an eastern extension and lithostratigraphic setup of Upper Indus Basin (Potwar sub-basin) is a good hope. 


\section{Gemstone and Jewelry Resources}

Azad Kashmir is producing gemstones and other minerals (Figure 1) (Figure 2) like bentonite, beryl, fluorite, garnet, hematite, limonite, margarite, mica, quartz, ruby, topaz and tourmaline [96]. Gemstones like green tourmaline/indicolite and rubellite from Gurais, black tourmaline/Schorl, garnet and quartz from Jandran Wala, aquamarine, beryl and topaz from Gurais and Donga Nar found in pegmatites and ruby from Nangimali, Kalajandar and Naril areas found in marble [9] [10] [11] [19] [22] [23] [28] [29].

Gold-silver-platinum: The platinum group represents platinum, palladium, rhodium, ruthenium, iridium and osmium. Gold, silver and platinum group are called noble metals. They are refractory, chemically inert and exhibit excellent catalytic activity. Gold and silver are being used for jewelry. Gold occurs mainly as native metal, or alloyed with silver and other metal as tellurides or associated with the sulphides of iron, silver, arsenic, antimony and copper. It also deposited by hydrothermal, metamorphic and replacement deposits and also nuggets and grains in residual or placer deposits. The silver used as photographic materials, in refrigeration and air conditioning industries. It is associated with copper, lead, zinc deposits or in combination with gold. Platinum group metals are used in automobile industry to reduce $\mathrm{CO}$ emission, in chemicals, petroleum refining, ceramics and glass, electrical and electronic industries, in jewelry, in dental and medicine like treatment of cancer, arthritis, radiotherapy, production of denture, etc. Platinum group are associated with mafic and ultramafic rocks, also in placers. Small amount of gold is also recovered by panning in the upper Indus and its tributaries. In Northern areas under Gold Exploration and Mineral Assessment Project (GEMAP), carried by Australian Assistance during 1992-95, the integrated sampling and geochemical maps were prepared. Gold was detected in many hundreds of drainage cells (tributaries). Among these 24 sites shows high anomalous gold. These anomalies are mostly associated with major shear zone/Indus Suture and some are porphyry type intrusives or altered carbonates [103]. Gold is found from Shontar and Shardi Nala and other places of upper reaches of Neelam River in Azad Kashmir. The Neelam valley is significant for gold exploration.

Ruby: Ruby deposits of Azad Kashmir are located in Khandigali-Nangimali-Khora-Katha, Chitta Ratta and Naril Nala areas of Neelam valley. They are associated with meta limestone and occur in calcite veins along bedding planes. The deposits are being mined and the reserves are estimated at about 24.9 million grams [155]. The ruby quality is excellent where phlogopite, fuchsite, chrom diopside, calcite and minor pyrite and muscovite are present. The size of light pink ruby crystal increases where graphite, pyrite and phlogopite are present with minor fuchsite. The gemological and mineralogical characters of Kashmir metamorphic ruby are very similar to Bermese ruby [156].

Garnet: The more common minerals are Pyrope (glowing red colour), almandine (brownish red to reddish violet colour), rhodolite (rose red colour and 
strong luster), spessartine (most exquisite orange hue), grossularite (brown, reddish brown, clear sparkling copper-gold to green), demantoid (unusual and rare among garnets and fancied for its brilliance and fire with refractive index 1.89. As a birthstone for those born in January, it symbolizes fidelity, friendship and constancy. A high quality orange red spessartine garnet has been recently discovered in pegmatites in Neelam valley of Azad Kashmir. This deposit has yielded large transparent crystals [8].

Sapphire: It is found in the Mochel, Pador Azad Kashmir [5] [114]. Mochel is approachable from the Zanskar side by the Umasi or the Pense Pass [5]. Saphire is obtained from surficial deposits [5].

Xenotime: It is $\mathrm{YPO}_{4}$ with REEs replacing Y. Xenotime is widespread accesory mineral in granite. It is misidentified with zircon. It is associated with zircon, monazite, allanite and other REEs. It is common detritial heavy mineral in sands and placer deposits. The Neelam and Reshian valleys of Azad Kashmir have wide exposures of granite which may yield xenotime gemstones.

Tourmaline: It is famous for its beautiful colors, occurring in all possible hues and shades. The more common hues are ruby red (rubellite), orange through brown to yellow, green and blue (indicolite). The gem varieties include rubellite, dravite, elbaite and liddicoatite [99]. It is believed to be stone for the October-born and is said to speed the writers' flow of thought. Green tourmaline has been found in pegmatites of Donga Nar in Azad Kashmir. Some of the best and fairly large specimens of bicolor and tricolor tourmaline have been found in these pegmatites [100].

Quartz crystals and Jewelry: These crystals can be used in best jewelry for attraction as diamond because India is famous due to using diamond in jewelry. Pakistan has many quartz crystals deposits. For detail, see in quartz veins title. It is used as gem and also used for dishes, optical instruments, spectacles, chemical, radio appliances, frequency control in electrical and radio apparatus. It is silicon dioxide and common rock mineral and also includes a number of ornamental varieties. The ornamental varieties can be crystalline such as amethyst and citrine or cryptocrystalline such as opal, agate, chrysoprase, chalcedony, and cornelion. The violet quartz or amethyst is the birthstone for the February born and to symbolize durability, friendship and stead fastness in love. Clear and well formed crystals of quartz occur in gem pegmatite in Azad Kashmir areas. Smoky and rose quartz occurs in these areas also.

Pegmatite gems and other mineral specimens: The reference [96] reported some other gemstones from Pakistan like agate, actinolite, amazonite (feldspar/microcline), azurite, epidote, jadeite (nephrite is a jade), Kunzite (transparent variety of spodumene pyroxene), margarite (the mineral of hydrated silicate of $\mathrm{Ca}$ and $\mathrm{Mg}$; with pearly luster from $\mathrm{AK}$ ), pargasite (hornblende), rutile, serpentine, turquoise (phosphate minerals), sapphire (blue variety of tourmaline), lapis lazuli (lazurite, feldspathoid group), tripoli (weathered chert/siliceous limestone), etc. 


\section{Metallic and non-metallic Mineral Resources}

Alum: It is potash alum or kaolinite $\mathrm{KAl}\left(\mathrm{SO}_{4}\right)_{2} 12 \mathrm{H}_{2} \mathrm{O}$. It is used for preservation of skin, mordant in dyeing, as an astringent in medicine and for removing suspended material from water. It occurs in alum shale which contains pyrites and undergoing decomposition. Alum is found with the coal associations in Devi Garh thrusted anticline, District Kotli. Nearly pure alunogen occurs in veins in with the sulphur and coal associations in Devi Garh (Khoi Ratta areas) thrusted anticline, District Kotli.

Bauxite: Bauxite is a heterogeneous material comprised of various aluminum oxide minerals such as gibbsite, trihydrate, boehmite, diaspore and monohydrates. Bauxite is the principal ore of aluminum, though in Russia nepheline syenite and in Sweden andalusite are the ores for high aluminum. Bauxite is used as manufacturing of aluminum, bauxite bricks for furnace, and making artificial abrasives. Laterite is used an iron ore when it has appreciable chemical and mineralogical composition. It is used in the manufacture of cement and in paints and pigments. Bauxite and laterite are residual deposits and the result of weathering and leaching. They are mainly located along disconformities in the Foreland basin. The bauxite is reported from Kotli and Muzaffarabad regions [157]-[160].

Muzaffarabad deposits occur in Infra Tertiary Indus Formation [9] [158] [160] of Indus Group deposited here in between the Cretaceous Kawagarh limestone and marl of Chichali Group; and overlying Early Paleocene Hangu Formation (sandstone, shale, coal and carbonaceous shale) followed by Late Paleocene Lockhart formations of Hangu Group; and Early Eocene Nammal (mainly shale) and Sakesar (coarse rubbly/nodular) limestone of Nammal Group, Chorgali (shale and limestone/dolomitic limestone) and Kuldana (red shale/muds, sandstone beds with some dolomitic limestone beds) formations of Kuldana Group, Miocene-Pliocene Murree Formation (alternating red muds and sandstone units). The bauxite is pisolitic and embedded in a clayey matter located just below the Hangu coal in Khila and surrounding areas in the overturned southern limb of southeastern plunge of Muzaffarabad anticline.

Kotli deposits occur in Infra Tertiary Indus Formation [9] [159] [160] of Indus Group deposited here in between the Cambrian? Abbottabad dolomitic limestone of Abbottabad Group; and overlying Early Paleocene Hangu Formation (sandstone, shale, coal and carbonaceous shale) followed by Late Paleocene Lockhart (fine rubbly/nodular) formations of Hangu Group; and Early Eocene Nammal (mainly shale) and Sakesar (coarse rubbly/nodular limestone and shale) of Nammal Group; Chorgali (green shale) and Kuldana (red shale/muds) formations of Kuldana Group, Miocene-Pliocene Murree Formation (alternating red muds and sandstone units). However in the Dodial anticline (at western end of Azad Kashmir just close to Potwar) the Murree Formation is laterally shifted into Miocene-Pliocene Potwar Group consisting of Chinji, Nagri and Dhok Pathan formations capped by Pleistocene-Holocene Soan Group consisting of Lei Con- 
glomerate (relatively coarse clastic) and Soan Formation (relatively fine clastic-shale/muds, sandstone and conglomerate). The bauxite is pisolitic, embedded in a clayey matter, $0 \%-12 \%$ boehmite, $0 \%-14 \%$ of gibbsite, $1.5 \%-10 \%$ quartz, $0 \%$ - 35\% chalcedony, 2\% - 89\% iron oxides (Ahmad and Siddiqi 1992). These deposits have been sporadically mined. The reserves of Dhanwan (alumina 41\% - $60 \%$, silica $18 \%$ - $40 \%$, iron $1 \%$ - $8 \%$ ) is $4.9 \mathrm{mt}$, Kamroti (alumina $50 \%-70 \%$, silica $9 \%-28 \%$, iron $1-2.5$ ) is $1.36 \mathrm{mt}$, Sawar (alumina $52 \%-56 \%$, silica $25 \%$, iron 5\%) is $0.93 \mathrm{mt}$, Dandili (alumina $34 \%-46 \%$, silica $36 \%-44 \%$ ) is $1.18 \mathrm{mt}$, Nakial (alumina $41 \%$ - $46 \%$, silica $13 \%-35 \%$, iron $2 \%-27 \%$ ) is $0.424 \mathrm{mt}$, Goi (alumina $47 \%$, silica $35 \%$ ) is $1.103 \mathrm{mt}$, Shisetar is $0.656 \mathrm{mt}$, Bermoach (alumina $51 \%$, silica $23 \%$ ) is $0.2 \mathrm{mt}$, Balmi (alumina $46 \%$, silica $31 \%$ ) is $0.209 \mathrm{mt}$, Khandar Karela is $0.209 \mathrm{mt}$ and Palan is $0.283 \mathrm{mt}$ with total $11.454 \mathrm{mt}$. [159] reported bauxite and coal along with other minerals in Kotli and Poonch districts of Azad Kashmir.

Copper-lead-zinc-silver: Showing of copper-lead-zinc is found from Surgan area of Neelam valley. The reference [161] reported discovery of Sulphide mineralization in Sawar area, Kotli district, Azad Kashmir. These mineralizations are found in Treri-Manjhotar area of Muzaffarabad and Sawar area of Kotli. The lead-zinc-silver is found in Siliji-Reshian area and may be in Neelam valley [39].

Feldspar: It is found from Kundal Shahi area of Neelam valley.

Fluorite: It is used as a flux in making steel, in the manufacture of white and coloured opalescent glass, in enameling cooking utensils, for the preparation of Hydrofluoric acid and elemental fluorine and also ornamental use. The fluorite $\left(\mathrm{CaF}_{2}\right)$ mineralization is found in the northern Indus suture and adjoining areas, like upper Neelam valley of Azad Kashmir.

Graphite: It is used for the manufacture of crucibles, stove polish, foundry facings, lead pencil, paint, lubricants and electrodes. For the manufacture of crucibles only flake graphite with graphite carbon in excess of $85 \%$ is used. It should be free from mica, pyrite and iron oxide. Amorphous graphite is used for paint and foundry facings and for this high purity is not needed. Artificial graphite is manufactured in large quantities from anthracite coal or petroleum coke in electric furnace. For lubricants, pencil and electric purposes high grade material is essential. In Pakistan no economic graphite deposits are found so far. Only amorphous graphite showings are found. Most of the accessibilities are difficult. It occurs in Mohriwali Baikh-bed is about $5 \mathrm{~m}$ thick [5] [162]. It is reported from Chota Kazi Nag mountain northern slope (Precambrian Salkhala series; [5]). It is also reported from Sarwali, Patlepani, Shontar Nar, Tarli Domel, Baqnuwan, Machyara, Batmag, Nauseri, Khilla, Reshian and Nikial-Mohra areas [9] [10].

Iron: The reference [136] reported iron ore resources of Pakistan. Iron (chamositic and glauconitic) and lateritic iron is associated with the Kotli and $\mathrm{Mu}-$ zaffarabad bauxitic localities. Limonite is found in Reshian and Cham area. Ankerite iron-lead-zinc is found in Kamroti-Nikial area. The chamositic and glauconitic iron is found in Yadgar section of Muzaffarabad District. Now recently 
the present authors discovered a micaceous hematite lenticular vein type small iron deposits [9] [78], Bala Pir area (close to Chela Bandi), Muzaffarabad. These micaceous hematite lenticular veins are surrounded by lateritic iron hosted by Precambrian Hazara Formation. Further some gypsum beds are also found in associations with the micaceous hematite mineralization and laterite. The large deposits of lateritic iron in Indus Formation are found in Kotli district. The small deposits of limonite/ocher are also found in the Lamnian area of Reshian valley, Hattian District, Azad Kashmir. In short Pakistan have large iron deposits but importing so far. So try should be made to reduce imports and use own country resources.

Mica: The used mica is muscovite, phlogopite (yellow to green copper or bronze red) and Lepidolite (rose red). Mica splits in to thin sheets which are strong, flexible, chemically inert, and transparent. Muscovite is used in electrical, machinery and other industries. Transparent sheets are also used for windows in coal, gas and oil stoves, gas lamps chimneys and lamp shades. Scrap mica is used in the manufacture of wall paper, lubricants, fancy paints, electrical insulators and micanite. Phlogopite is used as insulator in electrical apparatus. For commutators, phlogopite is preferred. Lepidolite is a common source of lithium compounds. Muscovite occurs in granites and syenites and pegmatites and also common in gneisses and schists. Phlogopite occurs in crystalline limestone, dolomite, schists and serpentine. Lepidolite occurs in pegmatite veins, granite, gneisses and sands. [139] and [128] reported mica from different northern areas. Sheet mica/muscovite and lithium mica/lepidolite is found in Ratti Gali, Donga Nar and Janowai area (limited production due to sporadic occurrences); and Surgin Neelam River and number of showings in Azad Kashmir. Among these the better deposits are the ones in the Neelam valley and near Astor [8]. In the Himalayan crystalline zone, mica deposits have been reported in the Neelam valley of Azad Kashmir. Among these the better deposits are the ones in the Neelam valley [8].

Millstone, quartzite and quartz powder: The hard and compact quartzite is found in Neelam valley area. Further the vast deposits of Tanawal quartzite are also found in Neelam valley of Azad Kashmir.

Pyrite: Pyrite may be used for the source of sulphur in the manufacture of sulphuric acid. Pyrite is disseminated in carbonaceous shale and coal between Nakial, Khandar and Tatt Pani in Kotli district. It is also found in Reshian. Further pyrite nodules are common in the shale, limestone, etc of different ages in Azad Kashmir.

Quartz veins: Many quartz veins reported in the Neelam valley

Rare earth elements (REE): These are found in Donga Nar and Gurais areas of Neelam valley [39]. Further REE can be explored and exploited from alluvial and placer deposits of Neelam and Jhelum rivers and their tributaries, for detail see above in Gilgit-Baltistan region.

Soapstone and talc: Talc is a hydrous silicate of magnesium while soapstone 
is an impure talcose rock in which talc is intimately mixed with various impurities such as dolomite, serpentine and calcite. Soapstone and Talc are mainly used in ceramics, paints, paper, cosmetic, plastic and insecticides. It is found in Machyara (Muzaffarabad), Palana and Newal (Kotli) dolomites. Soapstone small deposits occur as veins in Cambrian Abbottabad dolomite/dolomitic limestone of Nikial-Kamroti area, Kotli district and may occur also in Muzaffarabad and Neelam valley [39].

Tungston: Tungston is a silvery grey metal noted for its high melting point of $3410^{\circ} \mathrm{C}$ which is the highest of all metals. At high temperature it shows highest tensile strength. It is one of the heaviest elements (density 19.3) and has good corrosion resistance and good thermal and electrical conductivity. These properties enable its extensive use in the manufacture of drill bits, cutting edges of various machines, in electrical and electronics industries, in the manufacture of $\mathrm{X}$-ray tubes, heating elements, aerospace industry and in armour piercing artillery shells. It is also used in the manufacture of chemicals, dyes, paints, enamels and coloring glass. The main tungsten minerals are sheelite $\left(\mathrm{CaWO}_{4}\right)$, ferberite $\left.(\mathrm{FeWO})_{4}\right)$, huebnerite $\left(\mathrm{MnWO}_{4}\right)$, and wolframite $(\mathrm{Fe}, \mathrm{Mn}) \mathrm{WO}_{4}$. Most of the tungsten deposits in the world are contact metamorphic deposits, pegmatites, replacement deposits, hydrothermal fissure veins, stock works and related deposits or as placers. The tenor of tungsten ore is less than $1.0 \%$. Thus the low metal content and its irregular and erratic distribution in the deposit, makes it difficult to use large scale, low cost mining methods. Tungston may have found in Neelam valley. Placer sheelite may occur in the Neelam and Jhelum River [39].

\section{Agromineral Resources}

Phosphate: Phosphate is found economically in western vicinity of Azad Kashmir like Abbottabad areas. But in Azad Kashmir no economic phosphate is found so far, however some phosphatic nodules are found in the Paleocene-Eocene shale [39] [76]. Phosphate nodule upto $17 \% \mathrm{P}_{2} \mathrm{O}_{5}$ are found in Sakesar Limestone of Tatta Pani, Dhanwan, Nikial and Bangang areas of Kotli [39]. The reference [163] did not mention any significance phosphate deposits from Azad Kashmir.

Potash: Potash/alum is found and associated with Hangu coal (synonym Patala coal) in the eastern limb of Devi Garh thrusted anticline, Khoi Ratta area of Kotli district [39].

Limestone: Pakistan has vast deposits of limestone and marl both can be used for fertilizer because lime is best fertilizer for acidic soil which neutralizes the soil acidity. Calcium is essential element for normal growth of plants and activity of nitrifying bacteria (micro-organisms) and it regulates the supply of phosphorous for plants. Its deficiency can accumulate $\mathrm{Al}$ and $\mathrm{Mn}$ upto harmful concentration. For detail please see the cement raw and construction materials.

Gypsum: It has multi-uses like soil conditioning, cement resources, etc. Pl. sees in cement resources.

Cement Raw Material Resources 
Cement raw material includes limestone $75 \%$ and clays/shale $25 \%$ for clinker preparation and further it needs Gypsum 5\% as retarder. Pakistan has the lowest per capita consumption of cement. Further Pakistan is paying a lot of earning every year for calcium chemicals. It is highly desirable to take step for extending cement, lime and calcium chemicals industries, so that the country will be self-sufficient and able to export these materials to earn exchange. Recently authors found limestone deposits in Muzaffarabad and Lamnian area of Hattian district, Azad Kashmir can be used for cement industry. Further pozaloan for cement is found in Kalamula-Kailer-Lamnian-Nauseri belt. The cement industry can be installed at Lamnian, Hattian district Jhelum valley, Muzaffarabad and Nosehri (=Nauseri/Nausehri), Muzaffarabad districts, Neelam valley and Tatta Pani-Kamroti Nakial and Khoi Ratta, district Kotli, Azad Kashmir. The reference [164] reported cement raw material around Muzaffarabad, Azad Kashmir.

Limestone/dolomitic limestone: Limestone is extensively used as crushed stone for concrete aggregates, road metal and rail road ballasts. It is the basic raw material for cement. Limestone is also used in steel mills as fluxing agent, soil conditioner, as a source of lime, chemical raw material and as dimension stone. It is also used for building, statuary, monumental and ornamental purposes. The inexhaustible reserves of limestone are found in Pakistan. The limestone deposits are found in Muzaffarabad and Lamnian area of Hattian district, Azad Kashmir which can be used for cement industry.

clays/shale: Vast resources of shale are found in Azad Kashmir like Eocene Nammal shale and Chorgali shale in Muzaffarabad, Eocene Nammal shale in Tatta Pani-Nakial-Khoi Ratta areas (Kotli District) and Murree formation's shale every where in Azad Kashmir except upper Neelam.

Gypsum/anhydrite deposits: Gypsum is $\mathrm{CaSO}_{4} \cdot 2 \mathrm{H}_{2} \mathrm{O}$ and anhydrite is Ca$\mathrm{SO}_{4}$. Alabaster is fine grained and compact snow white to light smoky white with low hardness (1.5 - 2) and low specific gravity (2.2). Gypsum is used as retarder in cement, as a fertilizer, as filler in various materials such as paper, crayons, paints, rubber, etc and in the manufacture of plaster of Paris for which purpose the mineral is heated to expel some of its water of crystallization and then ground up. Calcined gypsum is extensively employed in the building trade for the production of various types of plasters, sheets, and boards and for stucco work; it is also used as polishing beds, in the manufacture of plate glass, and as an adulterant of foods. Very large deposits of gypsum are found in Pakistan. Although Small deposits of gypsum are found in Azad Kashmir like Precambrian Hazara formation of Reshian, Muzaffarabad and Neelam.

\section{Ceramic Mineral Resources}

Pakistan is importing glass, glass ware and pottery. Pakistan has very large resources of silica sand for manufacturing glass and glass wares. Further we have also large reserves of clays for manufacturing pottery. So import should be ceased and try to use own country resources.

Clay deposits: Clays/shales are used in earthenware works, brick making, 
mud houses, etc. Practically clays depend upon physical properties and specific test must be made for specific requirements. Chemical analyses have little value for the quality and its use. Various types of Clay deposits are found in Nammal, Sakesar, Chorgali, Kuldana and Murree formations of Azad Kashmir.

Bentonite/ fuller's earth: Bentonite commonly used for drilling muds. It is non swelling type of clay with white, grey and brown colours and high calcium \%. To convert them into swelling type, it is converted into sodium bentonites by Base Exchange process done by PCSIR in 1963. Origin of bentonite is redeposition of decomposed volcanic ash, tuffs and lavas of Permo-Carboniferous volcanics [165] or Tertiary volcanism [166]. Thin beds (upto few cms only) of bentonite are known in Bhimber-Mawa Kaneli and Samwal-Pothi-Karota in foothills of Azad Kashmir. Total cumulative reserves of all mentioned localities are 12,000 ton/metre of depth [166]. It is being produced from Punjab, Sindh, Khyber Pakhtunkhwa and Azad Kashmir. The reference [167] reported coal and bentonite deposits of Kotli Tehsil, Mirpur, Azad Kashmir. The reference [168] reported the bentonite resources of Punjab and adjoining areas of Azad Kashmir.

Fire clay: It is resistant to shrinkage, abrasion and corrosion under high temperature and withstands thermal spalling. It is very low in iron oxide content < $2 \%$ and high in alumina ( $24 \%-45 \%)$. Punjab is the main producer and consumer of fire clay. It is found from Kotli district. Small deposits (about 50,000 tons) of fire clay beds are found on the limbs of Tatta Pani anticlinorium, hosted by Indus Formation, just below the Hangu coal and just above the Indus Formation's Laterite and bauxite.

Limestone: It is being described under cement resources and also construction and dimension stones.

\section{Construction, Dimension and Decorative Stone Resources}

Azad Kashmir and Pakistan has large deposits of marble, dimension and construction resources [9] [10] [11] [142] [143] [144]. Large reserves of recrystallised limestone and marble occur in Azad Kashmir [9]. The present authors have found the large deposits (56 million tons) of white marble from Nausehri-Jhugian area of Azad Kashmir. Attractive and good quality quartzites found in Neelam valley of Azad Kashmir, Reshian-Lipa valley, Goi and Bangang area of Tatta Pani-Kotli. Granite is found from Neelam, Kundal Shahi, Jura, etc. Dolerite dykes from several localities especially from Neelam valley of Azad Kashmir provide jet black slabs for tiles and wall facings. Serpentine is found in the northern Indus Suture zones located in the uppermost part of Neelam valley. Large deposits of slate stone are found in Neelam, Reshian and Kalamula-Reji area of Bagh valley. Dolomite, marble and limestone are found in Muzaffarabad, Jhugian (13 mt) and Nauseri, Goi, Dhanwan, Nikial, etc. The private sector exclusively deals with the production, processing and marketing of marble and other decorative stones. Further recently authors found limestone deposits in Lamnian area of Hattian district, Azad Kashmir can be used for construction 
materials and also for cement industry. Some beds of sandstone of Murree formation in Azad Kashmir can be used for construction materials. Marble deposits have been found in the Nauseri and Jhugian areas [9] [77] of Lower Neelam valley, Muzaffarabad District, Azad Kashmir, Pakistan. These Marble deposits are product of metamorphism in the dolomitic limestones of Paleozoic-Mesozoic Abbottabad-Kingriali-Samanasuk-Panjal formations. By tectonic setting these marbles are sandwiched between Main Boundary Thrust and Khairabad-Panjal Thrust. Marble deposits are found on the eastern limb of Hazara-Kashmir syntaxis. The Nauseri marble area is located on Muzaffarabad-Neelam metalled road about $25 \mathrm{~km}$ east north east of Muzaffarabad city, while Jhugian Naka area is on the top of slender ridge trending toward Mahandri, Kaghan area (plunge of Hazara Kashmir syntaxis). These deposits are accessible from Muzafarabad, while Muzaffarabad is well connected with Islamabad and Abbottabad. On reconnaissance visit to see the generalized extension, these deposits are pinching toward Mahandri, Kaghan valley and also pinching towards Lamnian, Reshian valley. The marble is white, faint little blue tinge, translucent, pearly, massive and recrystallised. Two horizons of marble deposits are found in the Nauseri-Jhugian area of Muzaffarabad. The upper horizon is relatively thin while the lower horizon is relatively thick and workable/mineable. The lower horizon is thicker and being mined on the top of Nauseri-Jhugian area and being transported from top to base camp by motor driven rope and shovel systems. From base camp it is being transported further in the trucks to the market. This marble gives effervescence on acid drops confirming calcareous limy nature. The chemical results show $\mathrm{SiO}_{2}$ 10.34\%, $\mathrm{Al}_{2} \mathrm{O}_{3}$ 0.34\%, $\mathrm{Fe}_{2} \mathrm{O}_{3}$ 0.17\%, $\mathrm{CaO} 32.54 \%$, $\mathrm{MgO} 21.21 \%, \mathrm{Al}_{2} \mathrm{O}_{3} 0.34 \%, \mathrm{TiO}_{2} 0.027 \%, \mathrm{P}_{2} \mathrm{O}_{5} 0.001 \%$, Loss on ignition $35 \%$, $\mathrm{Na}_{2} \mathrm{O}$ and $\mathrm{K}_{2} \mathrm{O}$ are below detection limit. The chemical as well as petrographic study shows dolomitic limestone metamorphosed as marble which constitute the mineral composition as calcite $60 \%$, dolomite $30 \%$, Feldspar $8 \%$ and quartz $2 \%$. This white marble gives high reflectance and has great significance as good quality. Due to small deposits of such high reflectance and good quality marbles in the country is in high demand in Pakistan and also abroad like Saudi Arabia and Arab Emirates, etc. The present findings are highly valuable in mineral wealth of Azad Kashmir and consequently for Pakistan. Its development alongwith other mineral commodities of Azad Kashmir is an innovation for the sustainable development of Azad Kashmir. Considering 2 kilometer length and about 10 meter thickness and 1 kilometer easily mineable depth, the total easily mineable reserves are 56 million tons. Both horizons of marble are enveloped by igneous intrusions and volcanics of Panjal Group. This magma/lava is responsible for the metamorphism and birth of high quality with good reflectance marble in this area.

The marble, dolomitic limestone, limestone, sandstone, quartzite, granite, gneiss, gabbro, dolerite, conglomerate, aggregate/gravel and clays/shale resources are found in the area. Further vast deposits of sandstone and conglome- 
rate of Murree Formation are widely exposed in lower Kashmir from Muzaffarabad to Kotli-Mirpur. Mineral resources are non-renewable and therefore need careful sustainable exploitations. Dolomite occurs in Precambrian Hazara Formation (Salkhala Formation), Cambrian Abbottabad Formation, Jurassic Samanasuk dolomitic limestones and Eocene Chorgali Formation. Igneous along with some metamorphic rocks are found in the crystalline zone of Neelam valley, Northern Indus Suture. These large deposits of igneous rocks can be used for construction and other purposes. Igneous rocks like granite, dolerite, are being used. Tanawal quartzite, Hazara formations phyllite, slates are prominent in metamorphic rocks.

\section{Coal resources}

Large deposits of coal exist in Pakistan but unluckily Azad Kashmir share is very low [60] [61] [63]. The Azad Kashmir coalfields are found in the Early Paleocene Hangu Formation (previously called Patala) of Kotli and Muzaffarabad regions. Hangu and Patala formations both are the lateral extension and having same horizons, lithology and same basin justify only one name according to stratigraphic code, so Hangu is being preferred [9]. Further the new coal discovery in Azad Kashmir is found by authors in the Reshian area-a more than $1 \mathrm{~m}$ thick carbonaceous shale with some coal has been found in the Precambrian Hazara Formation in the Reshian area of Hattian District, Jhelum Valley. These coal seams seem to be metamorphosed to graphite in the Neelam valley of Azad Kashmir. Further the Kotli and Muzaffarabad coals are low grade. However the coal blending process like mixing of low quality coal with high quality coal by any methods like blending in bed, blending by silo, blending by ground hopper and blending on moving belt (most common) can produce required results for thermal power or any other uses [145]. Further the reference [146] mentioned many heavy mineral and elements in Thar coal suggests to observe these heavy minerals in all coal deposits of Pakistan and may be separated and exploited during wahing methods.

Kotli coal: Kotli Coal is known from 1876 in Azad Kashmir [167]. The heating value of Sarwar coal is $4545 \mathrm{BTU} / \mathrm{lb}$, Dandili coal is $6276 \mathrm{BTU} / \mathrm{lb}$, Mohra Sehri coal is $4300 \mathrm{BTU} / \mathrm{lb}$, Balmi coal is 10,217 BTU/lb and Bangang coal is 10,824 BTU/lb. The Engineers Combined Ltd Lahore [159] mentioned $4880 \mathrm{t}$ of Sarwar coal, $2905 \mathrm{t}$ of Dandili coal, 34,160 t of Mohra Sehri coal, $3325 \mathrm{t}$ of Balmi coal and $3659 \mathrm{t}$ of Bangang coal. ECL mentioned 54,988 t of coal reserves of Kotli areas. Contractors are facing problems of finding the market for this coal. The reference [169] mentioned the geology of coal occurrences of Kotli district.

Muzaffarabad coal: The reference [158] reported coal, bauxite and aluminous shales of Muzafarabad. Muzaffarabad coal is being mined Khila-Seri Dara-Maira Tanolian areas. It is new coalfield. It is found in the southeastern plunge of $\mathrm{Mu}$ zaffarabad thrusted anticline. The southwestern limb is overturned and also thrusted with active thrust evidences. The coal is hosted by the Latest Cretaceous-Early Paleocene Hangu Formation include $1.87 \mathrm{mt}$ deposits of coal with 
break up as $0.12 \mathrm{mt}$ measured, $0.25 \mathrm{mt}$ indicated and $1.50 \mathrm{mt}$ inferred [9] [10] [11] [61] [63].

\section{Petroleum Resources and Revised Stratigraphic Setup}

Hydrocarbons are the sigificat commodity for the industries and vehicle transportation. The upper Kashmir (Neelam valley) is not significant for petroleum exploration due to common igneous and metamorphic rocks, while lower Kashmir (the southern part of Azad Kashmir) belt namelu Muzaffarabad-Kotli-Mirpur belt is slightly significant for petroleum prospecting due to extension of Potwar sub-basin and its lithology. Northern (upper) Indus Basin consists of Precambrian to recent sequence more than $15 \mathrm{~km}$ thick. Indus Basin $\left(533,500 \mathrm{~km}^{2}\right.$ ) (a part of Gondwana) subdivided in to northernmost Indus (uppermost Indus or Khyber-Hazara-upper Kashmir or Khyber-Hazara-Neelam basin), northern Indus (upper Indus or Kohat-Potwar-lower Kashmir or Kohat-Potwar-Kotli basin), Central/middle Indus (Sulaiman basin) and southern/lower Indus (Kirthar basin) basins. The rectangle shape Sulaiman Basin is the largest basin of main Indus Basin and consists of more than $170,000 \mathrm{~km}^{2}$, while the triangle shape Kirthar basin more than $120,000 \mathrm{~km}^{2}$, square shape Kohat-Potwar-lower Kashmir basin more than $100,000 \mathrm{~km}^{2}$ and almost square shape Khyber-Hazara-upper Kashmir basin more than 100,000 km². The western Indus suture (Lasbela-Khuzdar-Quetta-Muslibagh-Zhob-Waziristan-Kuram) and northern Indus suture Mohmand-Swat-Besham-Sapat-Chila-HaramoshAstor-Shontar-Burzil Pass-Kargil), Kirana and Nagar Parkar areas shows more than 50,000 $\mathrm{km}^{2}$. Khyber-Hazara-Neelam Basin consists of basement Indo-Pakistan shield parts, metamorphic, sedimentary and igneous rocks poor in petroleum resources ranging in age from Precambrian to Recent. The Khyber-Hazara-Neelam basin is the extension of Kohat-Potwar-Kotli basin in the Paleo-downward slopes like north and northwest. In the Kohat-Potwar-Kotli basin the alternating terrestrial and marine conditions were dominant while in the Khyber-Hazara-Neelam basin the marine conditions were common showing occurrence on relatively deep sea. For example in the case of terrestrial Datta Formation which is terrestrial in upper Indus and marine in uppermost Indus.

Kohat-Potwar-Kotli Basin consists of Precambrian to recent sequence more than $15 \mathrm{~km}$ thick. It shows a large number of oilfields. The revised stratigraphic set up of Kohat-Potwar-Kotli Basin represents Precambrian Kirana Group (a part of Indo-Pak shield) and Salt Range Formation (marl, salt and gypsum; =Hazara/Salkhala slates), Cambrian Khewra group consists of Khewra (sandstone), Kussak (dolomite, siltstone and sandstone), Jutana (dolomite) and Baghanwala (red shale alternated with flaggy sandstone) and Khisor Formation (thick gypsum in the base and shale in the upper part); Early Permian Nilawahan Group consists of Tobra (Tillitic facies in eastern Salt Range, fresh water facies of siltstone and shale with pollen and spore flora, and a complex facies of diamictite, sandstone and boulder beds increase in westernsalt range and Khisor range), Warcha (speckled sandstone with some shale, Dandot is synonym) and 
Sardhi (greenish grey clay with some sandstone, siltstone and limestone); Late Permian Zaluch Group Amb (sandstone), Wargal (limestone) and Chidru (shale, quartzose sandstone with minor limestone). The Precambrian and Paleozoic rocks may extends into middle (Sulaiman) and Lower (Kirthar basins). The Triassic Musakhel Group consists of Mianwali (marl, limestone, sandstone, siltstone and dolomite), Tredian (terrestrial sandstone) and Kingriali (dolomite, limestone, dolomitic limestone, marl, sandstone and shale; Chak Jabbi is synonym) formations. The Jurassic Surghar Group comprises of Datta (terrestrial sandstone), Shinawari (shale, limestone) and Samanasuk (Limestone and minor shale) formations. The Cretaceous Chichali Group represents Chichali (green shale and sandstone), Lumshiwal (cross bedded sandstone and shale of continental origin), Kawagarh (marl and limestone-lateral facies of Lumshiwal Formation in downward slope) and Indus (laterite and bauxite, pisolitic, oolitic and green chamositic/glauconitic materials, ironstone, ferruginous and quartzose sandstone and claystone and fire clay) formations. The Paleocene Hangu Group consists of Hangu (synonym Patala; shale, sandstone and coal) and Lockhart (relatively fine nodular limestone as compared to Sakesar limestone) formations. The Early Eocene Nammal Group of Potwar sub-basin and eastern Kohat sub-basin consists of Nammal (green shale and muds) and Sakesar (coarse nodular/rubbly limestone) formations. The Panoba Group of western Kohat sub-basin consists Panoba (shale; equivalent to Shaheed Ghat shale of Sulaiman basin), Chashmai (green shale and sandstone; equivalent to Toi Formation of Sulaiman basin), Gurguri (brown shale and sandstone; equivalent to Kingri Formation of Sulaiman basin), Shekhan (limestone, shale; equivalent to Drug rubbly limestone of Sulaiman basin), Bahadurkhel salt and Jatta gypsum. Actually in the western Kohat the stratigraphy of Sulaiman basin is extending. So the terms of Chamalang/Ghazij and Kahan groups should be used in the western Kohat sub-basin. Chamalang (Ghazij) Group of Sulaiman basin represents Shaheed Ghat (shale), Toi (sandstone, shale, rubbly limestone and coal), Kingri (red shale/mud, grey and white sandstone), Drug (rubbly limestone, marl and shale), and Baska (gypsum beds and shale) formations. The Early-Middle Eocene Kuldana Group consists of Chorgali (shale and limestone and dolomite) and Kuldana (shale and marl with minor sandstone, limestone, conglomerate and bleached dolomite) formations. The Miocene-Pliocene Potwar Group (=Siwalik Group) include the Chinji (red and maroon muds), Nagri (sandstone) and Dhok Pathan (alternation of sandstone and red/maroon/brown muds) formations. The Pleistocene-Holocene Soan Group for the Pleistocene coarse clastic Lei (/Mirpur/Kakra) Conglomerate (massive conglomerate) and then Holocene mixed fine and coarse clastic of Soan Formation, concealed at places especially in the valleys and plain areas by the Subrecent and Recent fluvial, eolian and colluvial deposits.

Sulaiman Basin (Central/middle Indus) consists of exposed Mesozoic to recent sequence which is about $18 \mathrm{~km}$ thick. The Sulaiman Basin terminated in the 
south by the Khairpur-Jacobabad High line and in the north by Sargodha High line to Pezu to Kohat, in the east by Indo-Pak Shield exposures and in the west by western Indus Suture (Axial Belt) and Balochistan basin which is part of Tethys. It consists of Sulaiman fold and thrust belts, Sulaiman depression, southern Punjab monocline, Sukkur Rift areas like Kandkot main horst and Panno Aqil Graben. It contains two giant fields like Sui and Mari. This basin contains best reservoir (permeable sandstone/limestone/conglomerate), source (mostly shales) and cap (mostly shales) rocks. Triassic Khanozai Group represents Gwal (shale, thin bedded limestone) and Wulgai (shale with medium bedded limestone), Jurassic Sulaiman Group represents Spingwar (shale, marl and limestone), Loralai (limestone with minor shale), Chiltan (limestone) and Dilband (ironstone, etc) formations, Lower Cretaceous Parh Group represents Sembar (shale with a sandstone body), Mekhtar (sandstone, commonly called lower Goru, exposed in Mekhtar area of Loralai District), Goru (shale and marl), and Parh (limestone) formations, and Upper Cretaceous Fort Munro Group represents Mughal Kot (shale/ mudstone, sandstone, marl and limestone), Fort Munro (limestone), Pab (sandstone with subordinate shale) and Vitakri (red muds and greyish white sandstone) formations. The Paleocene Sangiali Group represents Sangiali (limestone, glauconitic sandstone and shale), Rakhi Gaj (Girdu member, glauconitic and hematitic sandstone; Bawata member, alternation of shale and sandstone), and Dungan (limestone and shale) formations; Early Eocene Chamalang (Ghazij) Group represents Shaheed Ghat (shale), Toi (sandstone, shale, rubbly limestone and coal), Kingri (red shale/mud, grey and white sandstone), Drug (rubbly limestone, marl and shale), and Baska (gypsum beds and shale) formations, and Early-Middle Eocene Kahan Group represents Habib Rahi (limestone, marl and shale), Domanda (shale with one bed of gypsum), Pir Koh (limestone, marl and shale) and Drazinda (shale with subordinate marl) formations, Oligocene-Pliocene Vihowa Group represents Chitarwata (grey ferruginous sandstone, conglomerate and mud), Vihowa (red ferruginous shale/mud, sandstone and conglomerate), Litra (greenish grey sandstone with subordinate conglomerate and mud), and Chaudhwan (mud, conglomerate and sandstone) formations, and Pleistocene-Holocene Sakhi Sarwar Group represents Dada (well developed conglomerate,mud and sandstone) and Sakhi Sarwar Formation (poorly developed conglomerate with subordinate mud and sandstone, while in centre of valleys the mud is dominant) concealed at places especially in the valleys and plain areas by Subrecent and Recent fluvial, eolian and colluvial deposits.

The latest Mesozoic and Cenozoic of Sulaiman Basin is well correlated with adjoining northern Balochistan (Kaker Khorasan) basin due to collision of Indo-Pakistan plate with Asian plate during Latest Cretaceous. Due to this collision the birth of Paleo Indus River systems occurs and ended the dynasty of Paleo Vitakri River systems. The Early Cretaceous Sembar (shale), Mekhtar (=lower Goru sandstone), Goru (shale and porcellaneous marl) and Parh (porcellaneous limesone) formations of Parh Group of Sulaiman basin is correlated 
with lower Cretaceous Akhtar Nika Formation (alternated porcellaneous limestone and shale; 1000 - $1500 \mathrm{~m}$ thick) of lower part of Sharan Jogezai Group. The Late Cretaceous Mughalkot (shale and sandstone), Fort Munro (limestone), Pab (sandstone) and Vitakri (shale and sandstone) formations of Fort Munro Group of Sulaiman basin is correlated with Late Cretaceous Jabrai Formation (mudstone/shale with alternation of porcellaneous thin marl/limestone beds; 500 $1000 \mathrm{~m}$ thick) of upper part of Sharan Jogezai Group (with type section about 20 $\mathrm{km}$ north of Qila Saifullah town). The Paleocene Sangiali (limestone and shale), Rakhi Gaj (sandstone and shale) and Dungan (limestone) of Sangiali Group of Sulaiman basin (=Ranikot Group of Kirthar basin) is correlated with Paleocene lower Nisai limestone (grey thick to massive), middle Nisai shale and upper $\mathrm{Ni}$ sai limestone (grey thick to massive) formations of Nisai Group (about $100 \mathrm{~m}$ thick) of Balochistan Basin. The Early to middle Eocene Shaheed Ghat (shale), Toi (sandstone and shale), Kingri (red muds and sandstone), Drug (rubbly limestone) and Baska (gypsum and shale) formations of Chamalang Group (=Ghazij Group), and Habib Rahi (limestone), Domanda (shale), Pirkoh (marl and shale) and Drazinda (shale) formations of Kahan Group of Sulaiman basin is correlated with Early to middle Eocene Shagala Group of Balochistan Basin. The Shaheed Ghat shale of Sulaiman basin is correlated well with Murgha Faqirzai Formation (shale, $2000 \mathrm{~m}$ thick) of Shagala Group, Toi Formation of Sulaiman Basin is correlated with the Mina Formation (alternation of green shale unit and sandstone unit; $3000 \mathrm{~m}$ thick) of Balochistan, the Kingri Formation of Sulaiman Basin is correlated with the Shagala Formation (=Shagalu; alternation of terrestrial red shale unit and sandstone unit; $3000 \mathrm{~m}$ thick) of Balochistan basin. At the hard contact of Indo-Pakistan plate with Asia at the end of Eocene resulted in the form of the Oligocene-Pliocene Vihowa Group (synonyms; Malthanai/Dasht Murgha group) in both basins. The Vihowa Group represents Chitarwata (which is the host of Buzdartherium gulkirao-a large rhinoceros mammals), Vihowa, Litra and Chaudhwan formations. The Pleistocene-Holocene Sakhi Sarwar Group (=Boston formation) represents Dada (conglomerate) and Sakhi Sarwar (mud and sandstone with poorly developed conglomerate, while in centre of valleys the mud is dominant) formations well developed in both basins.

Kirthar Basin (Southern/lower Indus) consists of exposed Precambrian to recent rocks more than $15 \mathrm{~km}$ thick. It consists of Kirthar fold and thrust belts, Jacobabad-Khairpur high/horst (Sukkur Rift), Kirthar depressions and Sindh monocline. The main reservoir rocks in Sindh monocline are Cretaceous Mekhtar Sandstone/Mekhtar Formation (Lower Goru sandstone) and from Karachi Depressions production is from Paleocene Ranikot group limestone and sandstone. In Kirthar depressions and Jacobabad-Khairpur high/Sukkur rift zone it may be from Eocene Habib Rahi and Paleocene Dungan limestone. The Mesozoic Stratigraphy of Kirthar basin can be seen in Sulaiman basin because Sulaiman and Kirthar basins have same Mesozoic stratigraphy, however differ in 
Cainozoic Stratigraphy. Paleocene Ranikot Group represents Khadro (sandstone, shale, limestone and volcanics), Bara (sandstone with minor limestone, coal and volcanics) and Lakhra (limestone and shale) formations; Early Eocene Laki Group represents Sohnari (lateritic clay and shale, yellow arenaceous limestone pockets, ochre and lignite seams) and Laki (shale, limestone, sandstone, lateritic clay and coal) formations, Early-Middle-Late Eocene Kirthar Group represents Kirthar (limestone, marl and shale) and Gorag (resistant and peak forming limestone with negligible shale and marl) formations, Oligocene Gaj Group represents Nari (sandstone, shale, limestone) and Gaj (shale with subordinate sandstone and limestone) formations, Miocene-Pliocene Manchar Group/Vihowa Group represents Chitarwata (grey ferruginous sandstone, conglomerate and mud), Vihowa (red ferruginous shale/mud, sandstone and conglomerate), Litra (greenish grey sandstone with subordinate conglomerate and mud), and Chaudhwan (mud, conglomerate and sandstone) formations, and Pleistocene-Holocene Sakhi Sarwar Group represents Dada (well developed conglomerate with subordinate mud and sandstone) and Sakhi Sarwar Formation (poorly developed conglomerate with subordinate mud and sandstone, while in centre of valleys the mud is dominant) which are concealed in the valleys and plain areas by the Subrecent and Recent fluvial, eolian and colluvial deposits. Thar is represented by eolian sand dune deposits.

\section{Radioactive Mineral Resources}

The radioactive minerals of uranium, thorium, etc occur primarily in the igneous rocks especially in the northern Indus Suture and igneous rocks of Neelam valley. It is found in graphitic schist and graphitic coal of Precambrian Salkhala formation and granite, etc in Reshian (ESE of Muzafarabad) and Neelam valley.

\section{Geothermal Energy Resources}

Geothermal hot spring sites are Tatta Pani, Kotli (Azad Kahmir with discharge of springs ranging from 0.5 to 30 litres per second and surface temperature from $35^{\circ} \mathrm{C}$ to $94^{\circ} \mathrm{C}$ ). The thermal water is neutral to slightly alkaline. $\mathrm{Na}$ is dominant cation in all cases with different anions like $\mathrm{HCO}_{3}, \mathrm{SO}_{4}$ and mixed type. The results indicate a good potential of these resources for industrial, domestic, electricity generation, heating and dry ice making purposes [153] [154]. Tatta Pani in Kotli (Azad Kashmir) can be benefitted especially in winter for Tatta Pani town.

\section{Water Resources and Dam Constructions}

Azad Kashmir has a lot of surface and ground water [9] [10] [11] [60] [160]. Surface water is represented by Neelam and Jhelum rivers and their tributaries, many lakes, Mangla Dam, diversion dams and surface runoff during and just after rains/heavy rains. Ground water aquifers occur in unconsolidated and consolidated sediments mostly of Miocene-Pliocene mollase of Potwar Group in lower Kashmir (Muzaffarabad to Kotli-Mirpur), in the fractures and pores of igneous and in metamorphic rocks in upper Kashmir (Neelam valley; Nausehri-Sharda-Kel-Taubat-Kargil). At places, the water aquifers are confined but 
mostly occur as open aquifers. Most of the springs in the areas supplies fresh water for domestic use and also partial sources of river water beside the melting of glacier ice. Hard rocks like igneous and metamorphic rocks have fractures due to thrusting created by geodynamics of Indo-Pakistan subcontinent. These fractures host water and, at places, yield as water springs, which is especially common in upper Azad Kashmir and Neelam valley. The glaciers in the Neelam valley are also among the main source of water for Pakistan. Hard rocks like sedimentary rocks of upper and lower Kashmir basins have a good bedding plane, porosity and fracture, hosting water and have a yielding capacity due to its primary and secondary permeability. In Azad Kashmir two main power projects like Neelam-Jhelum and Lowari tunnel projects are under way. The Neelam-Jhelum tunnel started at Neelam river (Nausehri) drop its load into Jhelum river (north of Kohala area). The Lowari tunnel started at Kunhar river (south of Lowari top) drop its load into Jhelum river (south of Muzaffarabad town). Both projects can play significant share or power and energy production. Furthermore, many suitable water dams and diversion dams on major rivers and tributaries should be constructed which are urgent needs due to congested and increasing population and large barren areas. There are numerous perennial streams of mountainous areas in Azad Kashmir with suitable water gradient and potential should be used for small diversion type hydel power plants to overcome the shortage of electricity/power/energy crises.

\section{Installation of global and national Geoparks and Museums}

Gilgit Baltistan and Azad Kashmir Pakistan has wonderfully exposed different types of igneous, metamorphic and sedimentary rocks, sedimentary rocks and minerals, typical sedimentary and tectonic structures, diverse topography like some plain areas and some world class peaks more than 29,000 feet above sea level such as K2, Nanga Parbat, broad peak (Falchan Kangri), many Muztagh (group of maintains) from east to west in Karakoram are Batura, Hispar, Panmah, Baltaro, Siachen, Rimo and Saser, many glaciers (more than $1 \mathrm{~km}$ deep) like Siachen $(74 \mathrm{~km})$ Baltaro $(62 \mathrm{~km})$, Batura $(58 \mathrm{~km})$, Godwin Austin, Biafo, Chogolisa, Gondokhoro, Hispar (53 km), Yazgil etc. Many mountainous peaks surrounded by

Pleasant and heaven valleys, rich minerals and gemstone, and many rivers like Gilgit, Indus, Jhelum offer opportunities for research, exploration and development. These areas represent both Gondwanan as well as Laurasian geoheritage. The protection of these geoheritages as national and global geoparks is an innovation for the sustainable development of science and Pakistan. Further gemstones museums in Gilgit Baltistan and Azad Kashmir play role for the development of the area. The northern part of Gilgit-Baltistan (especially Chapursan-Sost valley) represents Mesozoic marine and terrestrial sediments; these are significant for finding of vertebrate bones of Laurasian affinity while Azad Kashmir is significant for Gondwanan affinity. The paleontology, paleobiogeography, geodynamics and tectonic evolution are critical among world scientists 
because its Indus Basin was attached to Gondwana in the past but now connected with Asia. Pakistan is museum for many significant invertebrates and vertebrates. We should construct large museums of bones where the national and international researchers, students and visitors can access easily. The recent finding of fossils especially large vertebrates from Indus basin (while Kotli-Muzaffarabad of lower Kashmir is part of Indus basin) like poripuchian titanosaurs [170] [171] [172] [173] [174] and theropods [175] dinosaurs, mesoeucrocodiles [175] and pterosaurs [174] [175] of Gondwanan affinity, and large rhinoceroses [174] of Eurasian affinity from Sulaiman basin [174] and first time in Balochistan basin [174] and many other vertebrates, and invertebrates [174] from Pakistan are gifts for the scientists.

\section{Conflicts of Interest}

The author declares no conflicts of interest regarding the publication of this paper.

\section{References}

[1] Jan, M.Q. and Gauhar, S.H. (2013) Earth Sciences and Mineral Exploration History of Pakistan with Reference to Khyber Pakhtunkhwa and Its Adjacent Tribal Areas. Abstract Volume, Sustainable Utilization of Natural Resources of the Khyber Pakhtunkhwa and FATA, February 11, Peshawar, Pakistan. Journal of Himalayan Earth Sciences, Special volume 2013, 15-16

[2] Gee, E.R. (1949) Mineral Resources of North West India. Geological Survey of Pakistan, Record, 1, 1-25.

[3] Heron, A.M. (1950) Directory of economic minerals. Geological Survey of Pakistan, Record, 1, 1-69.

[4] Heron, A.M. and Crookshank, H. (1954) Directory of Economic Minerals of Pakistan. Geological Survey of Pakistan, Record, 7, 1-146.

[5] Ahmad, Z. (1969) Directory of Mineral Deposits of Pakistan. Geological Survey of Pakistan, Record, 15, 1-200.

[6] Gauher, S.H. (1969) Economic Minerals of Pakistan: A Brief Review. Geological Survey of Pakistan, Pre Publication Issue, 88, 1-110.

[7] Ahmad, Z. and Siddiqui, R.A. (1992) Mineral and Rocks for Industry. Geological Survey of Pakistan, Quetta, 325 p.

[8] Kazmi, A.H. and Abbas S.G. (2001) Metallogeney and Mineral deposits of Pakistan. Published by Orient Petroleum Incorporation, Islamabad, Graphic Publishers, Karachi, Pakistan, 264 p.

[9] Malkani, M.S. and Mahmood, Z. (2016) Mineral Resources of Pakistan: A Review. Geological Survey of Pakistan, Record, 128, 1-90.

[10] Malkani, M.S. and Mahmood, Z. (2017) Mineral Resources of Pakistan: Provinces and Basins Wise. Geological Survey of Pakistan, Memoir, 25, 1-179.

[11] Malkani, M.S., Alyani, M.I., Khosa, M.H. Somro, N., Arif, S.J., Tariq, S., Saeed, F., Khan, G. and Faiz, J. (2016) Mineral Resources of Pakistan-An Update. Lasbela University Journal of Science and Technology, 5, 90-114.

[12] Jones, A.G., Manistere, B.E., Oliver, R.L., Willson, G.S. and Scott, H.S. (1961) Re- 
connaissance Geology of Part of West Pakistan (Colombo Plan Co-Operative Project Conducted and Compiled by Hunting Survey Corporation). Government of Canada, Toronto, $550 \mathrm{p}$.

[13] Ahmad, Z. (1975) Directory of Mineral DEPOSITS of Balochistan. Geological Survey of Pakistan, Record, 36, 1-178.

[14] Malkani, M.S. (2011) Stratigraphy, Mineral Potential, Geological History and Paleobiogeography of Balochistan Province, Pakistan. Sindh University Research Journal (Science Series), 43, 269-290.

[15] Malkani, M.S., Mahmood, Z., Shaikh, S.I. and Arif, S.J. (2017) Mineral Resources of Balochistan Province, Pakistan. Geological Survey of Pakistan, Information Release, 1001, 1-43.

[16] Malkani, M.S. (2004) Mineral Potential of Siahan and North Makran Ranges, Balochistan, Pakistan. National Conference on Economic and Environmental Sustainability of Mineral Resources of Pakistan, Baragali, 20-22 July 2004, 46-47.

[17] Malkani, M.S. (2004) Stratigraphy and Economic Potential of Sulaiman, Kirthar and Makran-Siahan Ranges, Pakistan. In: Hussain, S.S. and Akbar, H.D., Eds., Fifth Pakistan Geological Congress, 14-15 April, Islamabad, Abstracts Volume, National Geological Society of Pakistan, Pakistan Museum of Natural History (Pakistan Science Foundation), Islamabad, 63-66.

[18] Malkani, M.S., Mahmood, Z., Arif, S.J. and Alyani, M.I. (2017) Revised Stratigraphy and Mineral Resources of Balochistan Basin, Pakistan. Geological Survey of Pakistan, Information Release, 1002, 1-38.

[19] Malkani, M.S. (2010) Updated Stratigraphy and Mineral Potential of Sulaiman (Middle Indus) Basin, Pakistan. Sindh University Research Journal (Science Series), 42, 39-66.

[20] Malkani, M.S., Mahmood, Z., Alyani, M.I. and Shaikh, S.I. (2017) Revised Stratigraphy and Mineral Resources of Sulaiman Basin, Pakistan. Geological Survey of Pakistan, Information Release, 1003, 1-63.

[21] Malkani, M.S., Mahmood, Z., Somro, N. and Shaikh, S.I. (2017) Revised Stratigraphy and Mineral Resources of Kirthar Basin, Pakistan. Geological Survey of Pakistan, Information Release, 1010, 1-59.

[22] Malkani, M.S., Khosa, M.H., Alyani, M.I., Somro, N., Zafar, T., Arif, J. and Aleem, M.Z. (2017) Revised Stratigraphic Setup and Mineral Deposits of Kirthar Basin (Lower Indus Basin), Pakistan. Lasbela University Journal of Science and Technol$o g y, 6,54-84$.

[23] Malkani, M.S. (2020) Revised Stratigraphy and Mineral Resources of Balochistan Basin (Pakistan): An Update. (In Process)

[24] Malkani, M.S. (2020) Cement Resources, Agrominerals, Construction, Marble, Dimension and Decor Stone Resources, Gemstone and Jewelry Resources of Pakistan; An update. (In Process)

[25] Malkani, M.S., Mahmood, Z., Somro, N. and Alyani, M.I. (2017) Cement Resources, Agrominerals, Marble, Construction, Dimension and Decorative Stone Resources of Pakistan. Geological Survey of Pakistan, Information Release, 1005, 1-23.

[26] Malkani, M.S., Mahmood, Z., Somro, N. and Arif, S.J. (2017) Gemstone and Jewelry Resources of Pakistan. Geological Survey of Pakistan, Information Release, 1004, $1-28$.

[27] Malkani, M.S., Mahmood, Z., Alyani, M.I. and Siraj, M. (2017) Mineral Resources of Khyber Pakhtunkhwa and FATA, Pakistan. Geological Survey of Pakistan, In- 
formation Release, 996, 1-61.

[28] Malkani, M.S., Khosa, M.H., Alyani, M.I., Khan, K., Somro, N., Zafar, T., Arif, J. and Zahid, M.A. (2017) Mineral Deposits of Khyber Pakhtunkhwa and FATA, Pakistan. Lasbela University Journal of Science and Technology, 6, 23-46.

[29] Malkani, M.S. and Mahmood, Z. (2016) Mineral Resources of Azad Kashmir and Hazara (Pakistan): Special Emphasis on Bagnotar-Kala Pani (Abbottabad, Hazara) New Coalfield. Journal of Himalayan Earth Sciences, ESP Volume 2016, 103.

[30] Malkani, M.S., Shah, M.R., Sajjad, A., Kakepoto, A.A. and Haroon, Y. (2013) Mineral and Gemstone Resources of Northern Khyber Pakhtunkhwa and FATA Regions, Pakistan-A Good Hope. Journal of Himalayan Earth Sciences, Special Volume 2013, 25-26.

[31] Malkani, M.S. (2013) Natural Resources of Southern Khyber Pakhtunkhwa and FATA Regions (Kohat Sub-Basin and Part of Northern Sulaiman Basin and Western Indus Suture), Pakistan-A Review. Journal of Himalayan Earth Sciences, Special Volume 2013, 30-31.

[32] Malkani, M.S. (2012) Natural Resources of Khyber Pakhtunkhwa, Gilgit-Baltistan and Azad Kashmir, Pakistan. Abstract Volume, Earth Sciences Pakistan 2012, June 23-24, Baragali Summer Campus, University of Peshawar, Pakistan. Journal of Himalayan Earth Sciences, 45, 70.

[33] Malkani, M.S., Mahmood, Z., Shaikh, S.I. and Alyani, M.I. (2017) Mineral Resources of North and South Punjab, Pakistan. Geological Survey of Pakistan, Information Release, 995, 1-52.

[34] Malkani, M.S. (2012) A Review on the Mineral and Coal Resources of Northern and Southern Punjab, Pakistan. Journal of Himalayan Earth Sciences, 45, 67.

[35] Malkani, M.S. (2020) Mineral Resources of North and South Punjab, Pakistan: An Update. (In process)

[36] Malkani, M.S., Mahmood, Z., Alyani, M.I. and Shaikh, S.I. (2017) Mineral Resources of Sindh, Pakistan. Geological Survey of Pakistan, Information Release, 994 1-38.

[37] Malkani, M.S. (2014) Mineral Resources of Sindh Province, Pakistan. Journal of Himalayan Earth Sciences, Volume ESP 2014, 57-58.

[38] Malkani, M.S. (2020) Mineral Resources of Sindh Province, Pakistan: An Update. (In process)

[39] Malkani, M.S., Mahmood, Z., Usmani, N.A. and Siraj, M. (2017) Mineral Resources of Azad Kashmir and Gilgit Baltistan, Pakistan. Geological Survey of Pakistan, Information Release, 997, 1-40.

[40] Malkani, M.S. (2014) Mineral and Gemstone Resources of Azad Kashmir and Gilgit-Baltistan (Pakistan). Journal of Himalayan Earth Sciences, Volume ESP 2014, 58-59.

[41] Malkani, M.S. and Mahmood, Z. (2016) Revised Stratigraphy of Pakistan. Geological Survey of Pakistan, Record, 127, 1-87.

[42] Malkani, M.S. and Mahmood, Z. (2017) Stratigraphy of Pakistan. Geological Survey of Pakistan, Memoir, 24, 1-134.

[43] Malkani, M.S. (2014) Revised Stratigraphy of Balochistan Basin, Pakistan. Journal of Himalayan Earth Sciences, Volume ESP 2014, 59-60.

[44] Malkani, M.S., Alyani, M.I., Khosa, M.H., Saeed, F., Haroon, A., Buzdar, M.A. and Kakar, A.S. (2015) Revised Stratigraphy of Indus and Balochistan Basins (Pakistan): 
Sea Level Changes and Land-Ocean Connections of Mesozoic and Cenozoic Strata. Lasbela University Journal of Science and Technology, 4, 21-27.

[45] Malkani, M.S. (2016) Revised Stratigraphy of Indus Basin (Pakistan): Sea Level Changes. In: Dzyuba, O.S., Pestchevitskaya, E.B. and Shurygin, B.N., Eds., Cretaceous Ecosystems and Their Responses to Paleoenvironmental Changes in Asia and the Western Pacific. Short Papers for the 4th Symposium of IGCP 608, 15-20 August 2016, Trofimuk Institute of Petroleum Geology and Geophysics, Siberian Branch, Russian Academy of Science (IPGG SB RAS), Novosibirsk, 96-99.

[46] Malkani, M.S. (2012) Revised Lithostratigraphy of Sulaiman and Kirthar Basins, Pakistan. Journal of Himalayan Earth Sciences, 45, 72.

[47] Malkani, M.S. (2020) Revised Stratigraphy of Northern Pakistan and Kohat-Potwar-Lower Kashmir Basin (Kohat-Potwar-Kotli-Muzaffarabad Basin) of Pakistan. (In process)

[48] Malkani, M.S., Shahzad, A., Umar, M., Munir, H., Sarfraz, Y., Umar, M. and Mehmood, A. (2016) Lithostratigraphy, Structure and Economic Geology of Abbottabad-Nathiagali-Kuldana-Murree Road Section, Abbottabad and Rawalpindi districts, Khyber Pakhtunkhwa and Punjab provinces, Pakistan. Journal of Himalayan Earth Sciences, Volume ESP 2016, 168.

[49] Malkani, M.S. and Mahmood, Z. (2016) Revised Stratigraphy of Uppermost Indus (Khyber-Hazara-Kashmir) Basin, Pakistan. Journal of Himalayan Earth Sciences, Volume ESP 2016, 105.

[50] Malkani, M.S. (2000) Preliminary Report on Gypsum Deposits of Sulaiman Range, Pak. Geological Survey of Pakistan, Information Release, 706, 1-11.

[51] Malkani, M.S. (2018) Cement Resources and Gypsum Deposits of Pakistan: Urgent Installation of Cement Industries in Daman of Sulaiman Range. Journal of Himalayan Earth Sciences, Volume ESP 2018, 180.

[52] Malkani, M.S. (2002) First Note on the Occurrence of Fluorite in Mula Area, Khuzdar District, Balochistan, Pakistan. Geological Survey of Pakistan, Information Release, 766, 1-11.

[53] Malkani, M.S. (2004) Discovery of Fluorite Deposits from Mula-Zahri Range, Khuzdar District, Balochistan, Pakistan. 5th Pakistan Geological Congress, Islamabad, 14-15 April 2004, 20-22.

[54] Malkani, M.S. (2012) Discovery of Fluorite Deposits from Loralai District, Balochistan, Pakistan. Journal of Himalayan Earth Sciences, 45, 69.

[55] Malkani, M.S. (2015) Mesozoic Tectonics and Sedimentary Mineral Resources of Pakistan. In: Zhang, Y., Wu, S.Z. and Sun, G., Eds., 12 th Symposium on Mesozoic Terrestrial Ecosystems (MTE 12), and 3rd Symposium of IGCP 608 Cretaceous Ecosystem of Asia and Pacific, 15-20 August 2015, Paleontological Museum of Liaoning/Shenyang Normal University, Shenyang, 261-266.

[56] Malkani, M.S., Alyani, M.I. and Khosa, M.H. (2016) New Fluorite and Celestite deposits from Pakistan: Tectonic and Sedimentary Mineral Resources of Indus Basin (Pakistan)-An Overview. Lasbela University Journal of Science and Technology, 5, 27-33.

[57] Malkani, M.S. and Mahmood, Z. (2017) Fluorite from Loralai-Mekhtar and Celestite from Barkhan, Dera Bugti, Kohlu, Loralai and Musakhel Districts (Sulaiman Foldbelt) and Karkh Area of Khuzdar district (Kirthar Range): A Glimpse on Tectonic and Sedimentary Mineral Resources of Indus Basin (Pakistan). Geological Survey of Pakistan, Information Release, 981, 1-16.

[58] Malkani, M.S. (2012) Discovery of Celestite Deposits in the Sulaiman (Middle In- 
dus) Basin, Balochistan, Pakistan. Journal of Himalayan Earth Sciences, 45, 68-69.

[59] Malkani, M.S. (2004) Coal Resources of Chamalang, Bahney Wali and Nosham-Bahlol Areas of Kohlu, Barkhan, Loralai and Musa Khel Districts, Balochistan, Pakistan. National Conference on Economic and Environmental Sustainability of Mineral Resources of Pakistan, Baragali, 20-22 July 2004, 44-45.

[60] Malkani, M.S. (2012) A Review of Coal and Water Resources of Pakistan. Journal of Science, Technology and Development, 31, 202-218.

[61] Malkani, M.S., Alyani, M.I., Khosa, M.H. Buzdar, F.S. and Zahid, M.A. (2016) Coal Resources of Pakistan: New Coalfileds. Lasbela University Journal of Science and Technology, 5, 7-22.

[62] Malkani, M.S. (2016) New Coalfields of Balochistan, Khyber Pakhtunkhwa, FATA and Azad Kashmir. Journal of Himalayan Earth Sciences, Volume ESP 2016, 53-54.

[63] Malkani, M.S. and Mahmood, Z. (2017) Coal Resources of Pakistan: Entry of New Coalfields. Geological Survey of Pakistan, Information Release, 980, 1-28.

[64] Malkani, M.S. (2018) Chamalang-Lunda-Nosham Coalfields of Balochistan, Pakistan: Foresight Strategy and Policy. Journal of Himalayan Earth Sciences, Volume ESP 2018, 26.

[65] Malkani, M.S. and Dhanotr, M.S.I. (2018) Kingri and Toi Nala (Ghoze Ghar-Savi Ragha) coalfields of Musakhel District, Balochistan, Pakistan: Foresight Strategy. Journal of Himalayan Earth Sciences, Volume ESP 2018, 21.

[66] Malkani, M.S. (2013) Coal and Petroleum Resources of Khyber Pakhtunkhwa and FATA (Pakistan)-An Overview. Journal of Himalayan Earth Sciences, Special Volume 2013, 27-29.

[67] Malkani, M.S. and Mahmood, Z. (2016) Coal Resources of Pakistan: New Coalfields of Balochistan, Khyber Pakhtunkhwa and Azad Kashmir. Journal of Himalayan Earth Sciences, Volume ESP 2016, 102.

[68] Malkani, M.S. and Shah, M.R. (2016) Chamalang Coal Resources and Their Depositional Environments, Balochistan, Pakistan. Geological Survey of Pakistan, Information Release, 969, 1-13.

[69] Malkani, M.S. and Shah, M.R. (2014) Chamalang Coal Resources and Their Depositional Environments, Balochistan, Pakistan. Journal of Himalayan Earth Sciences, 47, 61-72.

[70] Ahmad, W., Gauhar, S.H. and Siddiqui, R.A. (1986) Coal Resources of Pakistan. Geological Survey of Pakistan, Record, 73, 1-55.

[71] Ghaznavi, M.I. (2002) An Overview of Coal Resources of Pakistan. Geological Survey of Pakistan, Pre Publication Issue, 114, 1-167.

[72] Malkani, M.S. and Mahmood, Z. (2016) Clay (Ceramic) Mineral Resources of Pakistan: Recent Advances in Discoveries. Journal of Himalayan Earth Sciences, Volume ESP 2016, 101.

[73] Malkani, M.S. and Tariq, M. (2000) Barite Mineralization in Mekhtar Area, Loralai District, Balochistan, Pakistan. Geological Survey of Pakistan, Information Release, 672, 1-9.

[74] Malkani, M.S. and Tariq, M. (2004) Discovery of Barite Deposits from the Mekhtar area, Loralai District, Balochistan, Pakistan. National Conference on Economic and Environmental Sustainability of Mineral Resources of Pakistan, Baragali, 20-22 July 2004, 48 .

[75] Malkani, M.S. (2010) New Pakisaurus (Pakisauridae, Titanosauria, Sauropoda) Remains and Cretaceous Tertiary (K-T) Boundary from Pakistan. Sindh University 
Research Journal (Science Series), 42, 39-64.

[76] Malkani, M.S., Qazi, S., Mahmood, Z., Khosa, M.H., Shah, M.R., Pasha, A.R. and Alyani, M.I. (2016) Agromineral Resources of Pakistan: An Urgent Need for Further Sustainable Development. Journal of Himalayan Earth Sciences, Special Volume 2016, 51-52.

[77] Mahmood, Z. and Malkani, M.S. (2017) Good Quality Marble Deposits from Nausehri-Jhugian Area of Muzaffarabad Region, Neelam valley, Azad Kashmir (Pakistan). Geological Survey of Pakistan, Information Release, 978, 1-11.

[78] Malkani, M.S. and Mahmood, Z. (2017) Micaceous Hematite Deposit from Bala Pir-Bela Noor Shah Area of Muzaffarabad District, Azad Kashmir (Pakistan). Geological Survey of Pakistan, Information Release, 977, 1-10.

[79] Malkani, M.S., Qazi, S., Khosa, M.H., Shah, M.R., Zafar, T. and Arif, J. (2018) Iron, Laterite, Bauxite and Ochre Deposits of Pakistan: Emphasis on Feasible Dilband and Low Grade Fort Munro Ironstones. Journal of Himalayan Earth Sciences, Volume ESP 2016, 178-179.

[80] Malkani, M.S., Qazi, S., Khosa, M.H., Shah, M.R., Zafar, T. and Arif, J. (2018) Industrial Mineral Deposits of Pakistan: Significant for Sustainable Development of Pakistan. Journal of Himalayan Earth Sciences, Volume ESP 2018, 175-176.

[81] Malkani, M.S., Qazi, S., Shah, M.R. and Zafar, T. (2018) Sandstone Type Uranium Resources of Pakistan: Encouraging Huge Strata. Journal of Himalayan Earth Sciences, Volume ESP 2018, 167.

[82] Hayden, H.H. (1915) Notes on the Geology of Chitral, Gilgit and the Pamirs. Geological Survey of India, Record, 45, 271-335.

[83] Ali, S.T. (1959) Mineral Deposits and Showings in the Northern Part of Pakistan. Geological Survey of Pakistan, Information Release, 2.

[84] Ahmad, Z., Alam, G.S., Khan, R.N., Hussain, A., Khattak, A.K., Saleemi, B.A., Khan, R., Ahmad, S. and Qureshi, S.A. (1976) Investigation of Placer Mineral Deposits in the Indus, Gilgit, Hunza and Chitral Rivers, Pakistan. Geological Survey of Pakistan, Record, 36, 1-25.

[85] Ali, S.T. (1978) Mineral Resources of Pakistan. Geological Survey of Pakistan, Information Release, 105.

[86] Tahirkheli, R.A.K. and Jan, M.Q. (1979) Geology of Kohistan, Karakoram, Himalaya, northern Pakistan. Geological Bulletin of University of Peshawar, 11, 1-187.

[87] Ahmad, Z. (1981) Geological Sketch and Mineral Deposits of Azad Kashmir. Geological Survey of Pakistan, Record, 57.

[88] Jankovic, S. (1984) Metallogeny and Mineral Potential of Northern Pakistan (North of Indus Suture Zone): A Preliminary Assessment. Geological Survey of Pakistan, Record, 65, 1-25.

[89] Griffiths, J.B. (1987) Pakistan Mineral Potential: Prince or Pauper. Industrial Mineral, 238, 220-243.

[90] Grundstoff-Technik (1992) Pakistan's Mineral Wealth. Grundstoff-Technik GmbH, Essen., $72 \mathrm{p}$.

[91] Malik, R.H. (1995) Geology and Resource Potential of Azad Kashmir Ruby Deposits. In: Proceeding of Round Table Conference on Foreign Investment in Exploration and mining in Pakistan, Pakistan, 153-172.

[92] Gaetani, M., LeFoprt, P., Tanoli, S., Angiolini, L., Nicora, A., Sciunnach, D. and Khan, A. (1996) Reconnaisance Geology in Upper Chitral, Baroghil and Karambar Districts (Northern Karakoram, Pakistan). Geologische Rundschau, 85, 683-740. 
https://doi.org/10.1007/BF02440105

[93] Asad, A. (1996) Prospects of Mineral Resources and Industries in Northern Area of Pakistan. Geological Survey of Pakistan, Mineral Information Series, 16.

[94] Raza, H.A. and Iqbal, M.W.I. (1977) Mineral Deposits. In: Shah, S.M.I., Ed., Stratigraphy of Pakistan: Geological Survey of Pakistan, Memoir, Vol. 12, 98-120.

[95] Hussain, A., Ghaznavi, M.I. and Kazim, M.A. (2004) A Brief Overview of the Role of Geological Survey of Pakistan in the Mineral Sector Development. National Conference on Economic and Environmental Sustainability of Mineral Resources of Pakistan, Baragali, 20-22 July 2004, 23.

[96] Islam, N.U, Hussain, S.A., Abbas, S.Q. and Ashraf, M. (2010) Mineral Statistics of Pakistan. Geological Survey of Pakistan, Special Issue.

[97] Ali, S.T. (1967) Gemstones in Pakistan. Geological Survey of Pakistan, Pre Publication Issue, 63, 1-13.

[98] Gubelin, E.J. (1982) Gemstones of Pakistan: Emerald, Ruby and Spinel. Gems and Gemology, 18, 123-139. https://doi.org/10.5741/GEMS.18.3.123

[99] Kazmi, A.H. and O’Donoghue M. (1990) Gemstones of Pakistan. Gemstone Corporation of Pakistan, Pakistan, $146 \mathrm{p}$.

[100] Kazmi, A.H. (1995) Precious Stones of Pakistan. Proceedings of International Round Table Conference on Foreign Investment in Exploration and Mining in Pakistan, Islamabad, 16-18 October 1994, 57-75.

[101] Khan, T. and Kausar, A.B. (2010) Gems and Gemology in Pakistan. Special Publication of Geological Survey of Pakistan, 231 p.

[102] Ali, S.T. (1951) Alluvial Gold in Chitral (NWFP). Unpublished. Geological Survey of Pakistan File No. 549/1, 25, 1-21.

[103] Clavarino, J.G., Dawney, R.L. and Sweatman, T.R. (1995) Gold Exploration in Northern Areas, Status and Prospects. In: Proceedings of International Round Table Conference (1994) and Foreign Investment in Exploration and Mining in Pakistan, Govt of Pakistan and UN, Pakistan, 93-120.

[104] Khan, H. and Shah, M.T. (2004) Mineralogy of the Heavy Mineral Concentrates of Placers and Extraction of Placer Gold in the Bagrot Valley, Gilgit Agency, Northern Pakistan. National Conference on Economic and Environmental Sustainability of Mineral Resources of Pakistan, Baragali, 20-22 July 2004, 37.

[105] Miandad, S., Shah, M.T., Khan, S.D. and Ali, L. (2012) Preliminary Study of the rocks of Bagrot Valley, Gilgit-Baltistan, Pakistan with Emphasis on Gold and Base Metals Mineralization. Journal of Himalayan Earth Sciences, 45, 79-80.

[106] Tahirkheli, R.A.K. and Danilchik, W. (1959) An Investigation of Alluvial Sands for Uranium and Minerals of Economic Importance, the Indus, Gilgit, Nagar and Hunza Rivers, Gilgit Agency, Pakistan. Geological Survey of Pakistan, Information Release, 11 .

[107] Austromineral. (1976) Final Report. Indus Gold Project. Austromineral, Vienna, $235 \mathrm{p}$.

[108] Khan, S.R., Suzuki, M. and Khan, T. (1996) Gold Mineralization in the Kohistan Arc and Karakoram plate, Gilgit and Ghizar Areas, Northern Pakistan. Geologica, 2, 23-68.

[109] Khan, N.A., Shah, S.H., Khan, F. and Laghari, A.L. (1999) Occurrence of gold in Garesh area, Golgit district, Northern area, Pakistan. Geological Survey of Pakistan, Information Release, 692.

[110] Rehman, A., Shah, M.T., Khan, S.D. and Ali, L. (2012) Preliminary Investigations of 
the Rocks of Shigari Bala Area, Skardu, Gilgit-Baltistan, Pakistan in the Perspective of Gold and Base Metal Mineralization. Journal of Himalayan Earth Sciences, 45, 84-85.

[111] Sheikh, L., Shah, M.T., Khan, S.D. and Ali, L. (2012) Preliminary Study of the Rocks of Golo Das and Surrounding Areas, Gilgit-Baltistan, Pakistan in the Perspective of Gold and Base Metals Mineralization. Journal of Himalayan Earth Sciences, 45, 102-103.

[112] Ahmad, L., Khan, S.D., Shah, M.T., Jehan, N., Awais, M. and Sheikh, L. (2016) Application of Ore Microscopy, SEM-EDX and QEMSCAN Techniques for Study of Gold and Base Metals of Ladakh Island Arc, Gilgit-Baltistan, Pakistan. Journal of Himalayan Earth Sciences, Special Volume 2016, 22.

[113] Khan, B. (2013) Role of Pakistan Gems and Jewellery Development Company (PGJDC) in Promotion of Gems and Jewellery Sector of Pakistan. Journal of Himalayan Earth Sciences, Special Volume 2013, 21.

[114] Assistant Political Agent, Skardu (1956) A letter to Geological Survey of Pakistan. Geological Survey of Pakistan File No. 351(1), 1-24.

[115] Khan, F., Latif, M., Fayaz, A. and Khan, M.S.Z. (1987) Geology and mineral investigation of Hunza Nagar Area, Northern Areas, Pakistan. Geological Survey of Pakistan, Information Release, 291.

[116] Ashraf, M. and Hussain, K. (1994) Economic Geology and Mineralogy of PGE-Au in Dunite of Chilas, Northern Area, Pakistan. 2nd Segmite International Conference, Karachi, 11-14 April 1994, 20.

[117] Bhatti, N.A. and Alam, A. (1989) Heavy Mineral Analysis of Stream and Samples from Gilgit Agency. Geological Survey of Pakistan, Information Release, 336.

[118] Khan, T., Javaid, W., Amin, H.M.D., Arshad, M. and Jan, M.Q. (2018) Petrology of the Chilas complex of the Kohistan island arc in the Kiner Gah area, Chilas, Pakistan. Journal of Himalayan Earth Sciences, Volume ESP 2018, 13.

[119] Okrush, M., Bunch, T.E. and Bann, H. (1976) Paragenesis and Petrogenesis of a Coroundum Bearing Marble at Hunza (Kashmir). Mineralium Deposita, 11, 278-297. https://doi.org/10.1007/BF00203079

[120] Alam, G.S. and Cheema, M.R. (1974) Hunza Spinal (Ruby Spinal) Deposits, Hunza State, Gilgit Agency, Pakistan. Geological Survey of Pakistan, Information Release, 77.

[121] Kazmi, A.H., Peters, J.J. and Obodda, H.P. (1985) Gem Pegmatites of the Shingus-Dusso Area, Gilgit, Pakistan. The Mineralogical Record, 16, 393-411.

[122] Agheem, M.H. and Shah, M.T. (2004) Gems and Gem Bearing Pegmatites of the Shigar Valley, Skardu, northern Pakistan. National Conference on Economic and Environmental Sustainability of Mineral Resources of Pakistan, Baragali, 20-22 July 2004, 1.

[123] Kausar, A.B. and Khan, T. (1996) Peridote Mineralization in the Spat Ultramafic, Naran-Kohistan, Pakistan. Geologica, 2, 69-76.

[124] Butler, B.C.M. (1963) An Occurrence of Nephrite Jade in West Pakistan. Mineralogical Magazine and Journal of the Mineralogical Society, 33, 385-393.

https://doi.org/10.1180/minmag.1963.033.260.04

[125] Khan, T., Kausar, A.B. (2004) The Discovery of Rare Earth Bearing Gemstone (Bastnasite) in Pakistan. 5th Pakistan Geological Congress, Islamabad, 86.

[126] White, M.G. (undated) Copper, Lead, Zinc, Antimony and Arsenic in West Pakistan. Tech. Letter, Geological Survey of Pakistan. (Unpublished) 
[127] Kazmi, A.H. (1951) Notes on the Geology and Mineral Occurrences in Dainyor and Jotial nalas, NE and S of Gilgit. Geological Survey of Pakistan, file 534(15); 11 p.

[128] Kazmi, A.H. (1951) Preliminary Report on Geol. and Mineral Occurrences in Lower Hunza Valley. GSP, file 534(10), 1-13.

[129] Rehana, I. and Ahmed, S. (2004) Studies on the Spectroscopic Estimation and Excitation Behaviour of Arsenic and Other Elements of Economic Importance. National Conference on Economic and Environmental Sustainability of Mineral Resources of Pakistan, Baragali, 20-22 July 2004, 56.

[130] Bughio, G.M. and Khan, N.A. (1970) The Report on Copper Mineralization, Surgin Glacier Area, Gilgit Agency, Pakistan. Industial Development Corporation, 34 p. (Unpublished)

[131] Kausar, A.B. (1999) Hydrothermal Alteration and Sulphur Isotopic Study of Sulphide Deposits, Gilgit Area, Pakistan. Geologica, 4, 1-32.

[132] Khan, N.A., Shah, S.H., Laghari, A.L. and Mujtaba, G. (1987) A Preliminary Report on Occurrences of Sulphide Mineralization in Singal Area (42H/16) Gilgit District, Pakistan. Geological Survey of Pakistan, Information Release, 288.

[133] Shah, S.S. (1980) Lead Investigation in Lichi Area, Gilgit District. Geological Survey of Pakistan, Information Release, 114.

[134] Khan, A., Awais, M. and Hussain, Z. (2016) Geophysical Prospecting for Sulphide minerals in Barit-Danyore Nala, Gilgit Baltistan, Pakistan. Journal of Himalayan Earth Sciences, Volume ESP 2016, 19.

[135] Faruqi, S.H. (1997) The Graphitised Coal of Chapursan Valley, Upper Hunza Valley. Abst. National Symposium on Economic Geology of Pakistan. PMNH Islamabad, p. 31.

[136] Ali, S.T. (1963) Iron Ore Resources of Pakistan. CENTO Symp. Iron Ore. Isphahan, 55-60.

[137] Ali1, L., Moon, C.J., Williamson, B.J. and Arif, M., (2012) Identification of Target areas for Base Metal (Ni, Cr and $\mathrm{Co}$ ) Mineralization Based on GIS and QEMSCAN Analysis of Stream Sediments in the Ultramafic-Mafic Terrains along the Shyok Suture Zone, North Pakistan. Journal of Himalayan Earth Sciences, 45, 20.

[138] Cheema, M.R. and Alam, G.S. (1990) Pyrite Deposits of Naz Bar Area, Yasin Valley, Gilgit District, Northern Area, Pakistan. Geological Survey of Pakistan, Information Release, 333.

[139] Hayden, H.H. (1914) Notes on the Geology of Chitral, Gilgit and the Pamirs. Geological Survey of India, Record, 65, 1-271.

[140] Butt, K.A. and Qadir, A. (1987) Discovery of Lepidolite from Shingus Area, Gilgit, Pakistan, 1947-1989. Geological Bulletin, University of Peshawar, 14, 111-122.

[141] Riaz, A., Khan, A., Shah, M.T., Din, I., Khan, S. and Khan, S.D. (2017) Determination of Mercury in the Wild Plants with Their Soils along Indus, Gilgit and Hunza rivers. Journal of Himalayan Earth Sciences, 50, 35-40

[142] Asrarullah, (1963) Marble Deposits of West Pakistan. CENTO Symp. Indust. Rocks and Min. 179-188.

[143] Master, J.M. (1963) Limestone Resources of West Pakistan. In Symp. Lahore, 189-198.

[144] Ahmad, M. (1965) Marble in Pakistan. Geological Survey of Pakistan, Record, 17, pt 1.

[145] Nisar, S. (2018) Low Quality Coals Utilization-Key Commercial, Environmental 
and Plant Efficiency Consideration. Journal of Himalayan Earth Sciences, Volume ESP 2018, 12.

[146] Khan, Z. and Bibi S. (2016) Removal of Trace Elements from Thar Coal to Minimize Its Hazardous Effect on the Environment. Journal of Himalayan Earth Sciences, 49, 50-57.

[147] Butt, K.A. (1989) Uranium Occurrences in Magmatic and Metamorphic Rocks of Northern Pakistan. In: Uranium Deposits in Magmatic and Metamorphic Rocks, Proc. Tech. Committee Meeting, Salamanca, IAEA, Vienna, 131-134.

[148] Khaliq, A., Moon, C.G.A. and Syed, S.A. (2000) Survival Factor of Uraninite in the Major Rivers of Gilgit, Kohistan and Indus Basin, Northern Areas. 3rd South Asian Geological Congress, Lahore, September 2000, 38-139.

[149] Ali, M., Bano, S., Qureshi, J.A., Wasim, M., Khan, G., Begum, F. and Alam, M. (2019) Indoor and Outdoor Gamma Radiation Level in Mud and Concrete Houses and the Annual Effective Dose and Excess Life Time Cancer Risk in Gahkuch Ghizer Valley of Hindukush Range. Journal of Himalayan Earth Sciences, 52, 177-184.

[150] Sajid, M. (2018) Targeting the Rare-Earth Elements (REEs) Mineral Deposits in Khyber Pakhtunkhwa: The Productive Imprint of Pakistan-China Economic Corridor (CPEC). Journal of Himalayan Earth Sciences, Volume ESP 2018, 118.

[151] Khan, A., Faisal, S. and Rashid, M.U. (2018) Key Indicator Minerals and Chemistry for Carbonatites: A Review. Journal of Himalayan Earth Sciences, Volume ESP 2018, 70.

[152] Mussawar, U., Khan, S.F., Mussadiq, M., Ullah, M. and Ullah, S. (2016) Tectonic Evolution and Rare Earth Elements Potential of Pre and Syn-Orogenic Himalayan Carbonatites, Northwest Pakistan. Journal of Himalayan Earth Sciences, Special Volume 2016, 8.

[153] Bakar, M.A. (1965) Thermal Springs of Pakistan. Geological Survey of Pakistan, Record, 16.

[154] Bakht, M.S. (2000) An Overview of Geothermal Resources of Pakistan. Proceedings World Geothermal Congress 2000, Kyushu, 28 May-10 June 2000, 947-952.

[155] Malik, R.H. (1995) Geology and Resource Potential of Azad Kashmir Ruby Deposits. In: Proceedings of Round Table Conference of Foreign Investment in Exploration and Mining in Pakistan, Pakistan, 153-172.

[156] Baig, M.S. and Perveez, S. (2004) Structure and Ruby Mineralization of Khandigali-Nangimali Area, Neelam Valley, Azad Kashmir, Northwestern Himalaya, Pakistan. 5th Pakistan Geological Congress, Islamabad, 29-31.

[157] Fox, C.S. (1923) The Bauxite and Aluminous Laterite of India. GSI, Mem. 49, 1-287.

[158] Ali, S.T. (1955) Coal, Bauxite and Aluminous Shales of Muzafarabad. Geological Survey of Pakistan. (Unpublished)

[159] Engineers Combined Ltd Lahore (1979) Preliminary Mineral Survey in Kotli and Poonch Districts of Azad Kashmir. Report prepared for Azad Kashmir Mineral and Indust. Dev. Corp. Vol. (1): 25-58.

[160] Malkani, M.S. and Mahmood, Z. (2015) Geological Map of Part of Goi Quadrangle $43 \mathrm{~K} / 2$, Kotli District, Azad Kashmir, Pakistan. Geological Survey of Pakistan, Quetta, Scale 1:50,000.

[161] Siddiqui, R.A. and Saleem, M. (1976) Preliminary Repoprt on Discovery of Sulphide Mineralization in Sawar Area, Kotli District, Azad Kashmir. GSP IR 93.

[162] Ghaznavi, M.I. (1981) Graphite Deposits of Mohriwali, Upper Azad Kashmir. Geological Survey of Pakistan, Information Release, 167. 
[163] Stanin, S.A. and Hasan, M.S. (1966) Reconnaisance for Phosphate in West Pakistan.. Geological Survey of Pakistan, Information Release, 32, 1-17.

[164] Khan, R., Hussain, H. and Saleem, M. (1984) Cement Raw Material around Muzaffarabad, Azad Kashmir. Geological Survey of Pakistan, Information Release, 255.

[165] Bhola, K.L. (1947) Bentonite in India. Geol. Mining Metall. Soc. India. Journ, 19, 55-57.

[166] Ali, S.T. and Shah, I. (1963) The Bentonite Resources of Pakistan. Symposium on Industrial Rocks and Minerals, Lahore, December 1962, 153-160.

[167] Abdullah, S.K.M. and Rashid, M.A. (1960) Coal and Bentonite Deposits of Kotli Tehsil, Mirpur, Azad Kashmir. GSP. (Unpublished)

[168] Qureshi, M.K.A., Akhtar, M. and Bhutta, I. (2003) The Bentonite Resources of Punjab and Adjoining Areas of Azad Kashmir. Geological Survey of Pakistan, Information Release, $\mathbf{7 8 2}$

[169] Shah, S.H. and Bhutta, A.L. (1988) Geology of Coal Occurrences of Kotli District. Geological Survey of Pakistan, Information Release, 310, 1-29.

[170] Malkani, M.S. (2020) Pakisaurus balochistani (Poripuchia, Slender Titanosauria, Sauropoda) Associated Skeletons from the Latest Maastrichtian Vitakri Formation of Pakistan and Referred Fossils from India; Filling of significant missing links of Isisaurus colberti (Poripuchia, Slender Titanosauria, Sauropoda) found from Pakistan. Open Journal of Geology, 10, 408-447. https://doi.org/10.4236/ojg.2020.104019

[171] Malkani, M.S. (2020) First Skull of Medium Sized Titanosaur from Indo-Pakistan Subcontinent Found from the latest Maastrichtian Vitakri Formation of Pakistan; Associated Cranial and Postcranial Skeletons of Gspsaurus pakistani (Poripuchia, Stocky Titanosauria, Sauropoda) from Pakistan and India. Open Journal of Geology, 10, 448-489. https://doi.org/10.4236/ojg.2020.104020

[172] Malkani, M.S. (2020) First Snout with Complete Teeth Row of Titanosaur from Indo-Pakistan Subcontinent Found from the Latest Maastrichtian Vitakri Formation of Pakistan; Associated Cranial and Postcranial Skeletons of Saraikimasoom vitakri (Poripuchia, Stocky Titanosauria, Sauropoda) from Pakistan and referred fossils from India. Open Journal of Geology, 10, 368-407. https://doi.org/10.4236/ojg.2020.104018

[173] Malkani, M.S. (2019) Cretaceous Stratigraphy of Pakistan. Open Journal of Geology, 9, 671-673. https://doi.org/10.4236/ojg.2019.910071

[174] Malkani, M.S. (2019) Recently Discovered Basilosaurid, Baluchithere Rhinoceros, Horses, Sea Cow, Proboscidean, Eucrocodile, Pterosaurs, Plesiosaur, Fishes, Invertebrates and Wood Fossils, Tracks and Trackways of Dinosaurs from Pakistan; Comparison of recognized four Titanosaur taxa of Indo-Pakistan with Madagascar. Open Journal of Geology, 9, 919-955. https://doi.org/10.4236/ojg.2019.912098

[175] Malkani, M.S. (2020) Theropods, Mesoeucrocodiles and Pterosaurs Found from the Latest Maastrichtian Vitakri Formation of Balochistan, Pakistan; Description with Large Photographs and Comparison with Coeval Taxa from Indo-Pakistan Subcontinent. Open Journal of Geology, 10, 510-551.

https://doi.org/10.4236/ojg.2020.105023 